\title{
Beyond Agricola: The Multiple Origins of European Knowledge in Adam Schall von Bell's Chinese Mining and Metallurgy Handbook Kunyu Gezhi (1640)
}

\author{
Alexander JOST 曹大龙 ${ }^{1}$
}

(Salzburg University, Salzburg 5020, Austria)

\begin{abstract}
In 2015, a previously unknown manuscript was discovered in the Nanjing Library. It contained a Chinese mining and metallurgy handbook, and was identified as a copy of the Kunyu gezhi 坤輿格致, known as the lost Chinese translation of Georgius Agricola's (1494-1555) De re metallica (1556) by Jesuit Adam Schall von Bell (1592-1666). A closer look at the text, however, reveals that, besides parts of Agricola's book, content by at least four other European authors was included: Vannoccio Biringuccio (1480-1539), Modestinus Fachs (?-before 1595), Lazarus Ercker (1528/301594), and José de Acosta (1539/40-1599/1600). This study demonstrates how their books became available in China, why they were selected as sources for the Kunyu gezhi, and how they were eventually used and incorporated. From this, it becomes apparent that Schall and his collaborators spared no effort to conduct this ambitious knowledge transfer project, and to present European technology at its best to the emperor.
\end{abstract}

Received: August 21, 2020. Revised: October 29, 2020.

This paper has been copyedited by John Moffett.

* This research is part of "Translating Western Science, Technology and Medicine to Late Ming China: Convergences and Divergences in the Light of the Kunyu gezhi 坤興格致 (Investigations of the Earth's Interior; 1640) and the Taixi shuifa 泰西水法 (Hydromethods of the Great West; 1612)," a project supported by the German Research Foundation (DFG) from 2018 to 2021. The project is carried out at the Department of Chinese Studies at Tübingen University, Germany. I would like to thank the project leader Hans Ulrich Vogel, as well as project members Cao Jin 曹 晋 and Sabine Kink, for their critical and helpful comments. My further gratitude is also owed to Zhao Daying 赵大莹 from the National Library of China, and to Noël Golvers from KU Leuven for their support with some important details as well as to John Moffett for his diligent proofreading and to the anonymous reviewers for their useful suggestions.

1 Research interests: Processes of communication, transfer and exchange between China, Europe, and the Islamic world in the middle and early modern periods. Among other topics, Alexander Jost has published on the establishment of hydrometallurgy in Song China, diplomatic relations between Ming China and Rasulid Yemen, and the practice of Hajj pilgrimage by Chinese Muslims. Email: alexander.jost@sbg.ac.at. 
Keywords: Jesuits, translation, De re metallica, Kunyu gezhi, Agricola, Adam Schall von Bell, history of Ming, history of metallurgy, knowledge transfer, Ming dynasty

摘 要: 2015 年, 南京图书馆藏的一份不为人知的手稿引起了学界的重视。经鉴定, 这 一矿冶著作是被认为失传已久的《坤與格致》的一个抄本。《坤與格致》此前被普遍视 为耶稣会士汤若望 (Adam Schall von Bell, 1592 1666) 对阿格里科拉 (Georgius Agricola, 1494 1555) 的《矿冶全书》（De re metallica，1556）的中译本。然而, 仔细 阅读文本可以发现, 该书除了编译《矿冶全书》中部分内容外, 至少还收录了另外四位 欧洲学者的著述, 他们是万诺乔 - 比林古乔 (Vannoccio Biringuccio, 1480 1539)、莫 德斯蒂努斯 - 法克斯 (Modestinus Fachs，? 1595 前)、拉扎勒斯 - 埃克（Lazarus Ercker, 1528/30 1594) 和何塞 - 德 - 阿科斯塔 ( José de Acosta, 1539/40 $1599 / 1600$ )。本文通过这一个案研究, 展示了上述学者的著作是如何来到中国、因何被 选为 《坤與格致》的参考书目, 以及最终是如何被使用和吸收的。从这一过程可知, 汤 若望和他的合作者不遗余力地进行这项雄心勃勃的知识转移工程, 将欧洲的技术以最好 的方式呈现给了崇祯皇帝。

关键词: 耶稣会士, 翻译, 《矿冶全书》, 《坤與格致》, 阿格里科拉, 汤若望, 矿冶史, 知识转移

\section{The Kunyu gezhi manuscript}

Following the arrival of Michele Ruggieri (1543-1607) and, especially, Matteo Ricci L (1552-1610) in Macau in 1579 and 1582, the growing communities of Jesuit throughout the country, developed into expert agents of knowledge transfer between Europe and China. Together with a network of converts and other supporters, which reached into the highest layers of Chinese society and administration, they were able to successfully present early scientific thought and useful knowledge from the West to their host country with the final aim to convince everyone, most importantly the emperor, of the superiority of their worldviews, and thus of the Catholic faith. Their publications, mostly co-authored by European missionaries and Chinese collaborators, covered a wide range of topics beyond religion, ranging from astronomy through cartography, mathematics, mechanics, medicine, and military technology to clockmaking, agriculture, and hydraulic engineering, to name but a few. Some of these smaller and larger knowledge transfer projects had a lasting impact in China, others were merely considered as curiosities, surviving among interested specialists until today, while yet others were lost, with only the listing of their titles in catalogues or citations bearing fragmentary witness to their former existence. One such project was initiated with high hopes in the 1630s to rescue the desperate state finances of the late Ming dynasty, and was led in a concerted effort by the famous Jesuit Johann Adam Schall von Bell (1592-1666, Chinese name Tang Ruowang 湯若望) and Li Tianjing 李天 
經 (1579-1659), then head of the imperial Calendar Bureau (Liju 曆局). ${ }^{2}$ Acting upon their suggestion, the Chongzhen emperor (r. 1627-1644) himself patronized this project, and, after heated controversy at the court, eventually decided to have the resulting book printed with numerous illustrations and distributed throughout the country. However, all trace of this work, named Investigations of the Earth's Interior (Kunyu gezhi 坤輿格致, hereafter KYGZ), a comprehensive almanac of European mining, smelting, and assaying technology in Chinese, vanished during the chaos of the Ming-Qing transition, before imperial order could be restored. For a long time, its exact content and the sources upon which it was based have been only a matter of speculation.

Information about it could be found in a number of surviving archival documents from the last decade of Ming rule, where it is mostly described as a translation based on one Western book also bearing the title Kunyu gezhi. ${ }^{3}$ Long after its disappearance, its title has been listed by several modern authors over the course of the twentieth century, such as Henri Bernard $(1945,355)$ and Joseph Needham (Needham and Lu 1974, 335; Needham, Ho, and Lu 1976, 235-236), as a Chinese translation of the famous standard work De re metallica (Agricola 1556) by Georgius Agricola (1494-1555).

The work received increased attention in the 1980s, when the circumstances of its compilation and disappearance were analyzed in great depth by Pan Jixing 潘吉星 (Pan 1983; Pan, Vogel, and Theisen-Vogel 1989) and Hans Ulrich Vogel (Vogel 1989; Pan, Vogel, and Theisen-Vogel 1989). As the KYGZ itself was lost, these studies still had to rely on secondary evidence alone, and, as before, consequently also depicted the KYGZ as a mere translation of De re metallica. However, this situation changed when in April 2015 Han Fengran 韩风申, a compiler and editor at the Phoenix Publishing \& Media, discovered a manuscript with the first page missing in the Nanjing Library 南 京图书馆, and identified it as the lost KYGZ.4 With this text in hand, it has now become

2 This cooperation was carried out within the structure of the Calendar Bureau (Liju 曆局) under the lead of scholar-official Li Tianjing 李天經 (1579-1659), and with the support of the two junior officials Yang Zhihua 楊之華 (?-1641) and Huang Hongxian 黃宏憲 (?-before 1683). 3 See Li Tianjing's two memorials preserved in Zengding Xu Wending gong ji 增訂徐文定公集 (Xu 1962a, 4:85-88).

4 The original manuscript in the Nanjing Library has the call number GJ/EB/120275. The earliest news article related to it was written by Han Fengran 韩风申 (Han 2015a) on April 26, 2015. See also Han (2015b). The manuscript was later published in an edited version (Zhou 2017, vol. 8). When the Kunyu gezhi (KYGZ) is cited in this article, the pagination follows the original Nanjing manuscript version.

The translation of the Kunyu gezhi will be published as a separate volume by Prof. Dr. Hans Ulrich Vogel, Dr. Cao Jin, and Sabine Kink, MA, with the assistance and/or contributions of Dr. Alexander Jost, Prof. Dr. Beatriz Puente Ballesteros, Sebastian Demuth, MA, Dr. Edward Yong Liang, Dr. Ailika Schinköthe, and Prof. Dr. Christine Moll-Murata. The translation is the result of Prof. Vogel's translation seminar, which takes place weekly during the teaching period and is also open to MA and PhD students. Other members of the Department of Chinese Studies at Tübingen University who regularly took part in these sessions and who offered their critical 
possible to thoroughly analyze the content and language of the work, and to find answers to questions such as: From which Western source or sources did Schall and his collaborators obtain the knowledge included in the KYGZ? In which ways did they translate or reformulate it? How close did the result come to the aim of successfully transferring this highly diverse and technical knowledge into the linguistic and cultural setting of late Ming China? And did this ambitious project influence the further development of the Chinese mineral industries in any way despite its early disappearance? This article mainly deals with the first question concerning the Western sources of the KYGZ.

The expectation that the KYGZ might provide an explicit answer itself is soon dispelled. While other works, such as for instance the famous Diagrams and Explanations of the Wonderful Machines of the Far West (Yuanxi qiqi tushuo 遠西奇器圖說, 1627. Hereafter “YXQQTS”) by Johann Schreck (1576-1630, Chinese name Deng Yuhan 鄧玉 函) and Wang Zheng 王徵 (1571-1644), at least provide some names of European authorities their content might be based on - in its case Guidobaldo del Monte (Weiduo 未多, 1545-1607)5, Simon Stevin (Ximen 西門, 1548/49-1620), Agostino Ramelli (Lamoli 刺墨里, 1531-1600) and Georgius Agricola (Gengtian 耕田, lit. “field tiller," i.e. Agricola) (Zhang et al. 2008, 93-94; Pan, Vogel, and Theisen-Vogel 1989, 164). ${ }^{6}$ The newly discovered manuscript, unfortunately, remains silent in this respect. Other sources from the hands of its compilers, though, provide some hints. In a memorial dated July 31, 1639, Li Tianjing writes:

In the spare time left after the revision and correction of the calendar regulations, I, together with the calendar reviser and subject from afar Tang Ruowang and others, and in obeisance of an Imperial Edict, have taken care of delving into collateral matters in an

comments are Guo Aiting, MA, Prof. Dr. Achim Mittag, and Anna Strob, MA. For each session the translation of a section of the text is prepared by an individual member of the group. This is then discussed collectively, with Hans Ulrich Vogel, Cao Jin, and Sabine Kink responsible for the final revision and editing of the translation, and with important input from Alexander Jost, who is responsible for searching for the origins of relevant information in Western sources. This labor division and work flow is reflected when quoting translations of the KYGZ text, and is done in the following ways: Kink (trans.), Vogel \& Cao (rev. \& ed.); Cao (trans.), Vogel \& Kink (rev. \& ed.); Puente-Ballesteros (trans.), Vogel, Cao \& Kink (rev. \& ed.), etc. See also Vogel (2015); Vogel [Fu Hansi] and Cao (2016).

5 In earlier studies, "Weiduo" has been identified with Vitruvius (80/70-15 BCE) (Verhaeren 1947, 185-186) and with Vittorio Zonca (1568-1602) (Needham and Wang 1965, 211-225). As Zhang Baichun et al. show based on Fritz Jäger's research (Jäger 1944), however, in the context of the YXQQTS, Guidobaldo del Monte, as a major proponent of European Renaissance mechanics, is a better fit (Zhang et al. 2008, 1:93).

6 The first chapter of the YXQQTS mentions Agricola together with Ramelli as two great illustrators of European machines. Other than from Ramelli's work, no illustration by Agricola was used by Schreck and Wang. The only possible traces of De re metallica in the YXQQTS can be found in its Glossary (Zhang et al. 2008, 1:94). 
endeavor to respond with gratitude [to the Imperial Favors received]. Among the [works] picked out there was this one book Kunyu gezhi from the Western Schools. ${ }^{7}$

This statement clearly speaks about only "one Western book." It is moreover evident that this book's name, Kunyu gezhi, is the title that was chosen for the Chinese book, and that no direct translation of the book title De re metallica or of the title to any other known Western book on mining existed during the time under consideration. He repeats his statement in a later administrative communication twice, writing:

with regard to this one book, Kunyu gezhi, that had been submitted [three years ago] to the Throne, His Majesty orders the Grand Secretaries to summon the respective ministries to discuss it quickly and respond [to the Emperor]. . . . I venture to inform you that concerning this one book, Kunyu gezhi, while having been watching with deep concern the period of troubles [in our country] and indeed not having been able to assist the Account Keepers in one [of the state] budgets, it happened that Tang Ruowang, the subject from afar and reviser of the calendar, had [indeed] selected this book from the books that had been brought along from his country. As it really is of benefit to the state budgets, [we] had it subsequently translated, and had it handed in twice to the Throne together with the illustrations. ${ }^{8}$

It is thus obvious that $\mathrm{Li}$ Tianjing either holds the opinion that all or almost all the content of the KYGZ is translated from one Western book, and is not aware of this book's original title, or at least for the sake of simplicity he communicates the situation in this way to the Chongzhen emperor.

Even if the KYGZ was in fact only translated from one source, it is unlikely that this was for the reason that Schall would not have had access to more books on the topic. At least, when Tan Qian 談遷 (1594-1658) visited Schall fourteen years later in 1654 in Beijing he recorded in his diary:

7 “惟于修政歷法之餘、同修歷遠臣湯若望等、遵旨料理、旁通諸務、以圖報稱、簡有西庠坤興格 致一書。”

“Ming tishu" 明題疏 [Memorials of the Ming (Period)], i.e. the “Zhili yuanqi" 治曆緣 起 [Origins of the Regulations of the Calendar] part of the Chongzhen lishu 崇禎曆書 [Calendrical Treatises of the Chongzhen (Reign-Period)], manuscript of the Tokyo Observatory (Tōkyō tenmondai 東京天文台), now in the Library of National Astronomical Observatory of Japan. See http://library.nao.ac.jp/kichou/archive/7012/kmview.html (accessed August 20, 2020). Memorial by Li Tianjing “Ti wei dai xian churao yi yu guochu shi” 題為代獻葱茥以裕國儲事 (Memorial in Lieu [of Schall von Bell] with Amateurish and Worthless Proposals for Enriching the State Treasury). Emphasis added. Translation: Vogel (trans.), Cao \& Kink (rev. \& ed.).

8 “奉上傳李天經所奏坤興格致一書, 著輔臣傳該部, 速為議覆……鏑炤坤興格致一書, 向因蒿目 時艱, 未能仰佐司計一籌, 乃值修歷遠臣湯若望, 簡有本國携來此書, 誠有禆于國計者, 遂爾翻 譯, 兩次繪圖䋨進。”

KYGZ, Li Tianjing “Hui Cisi shouben" 回祠司手本 [A Communication Answering to the Bureau of Sacrifices (of the Ministry of Rites)]. Emphasis added. Translation: Vogel (trans.), Cao \& Kink (rev. \& ed.). 
Tang has a very rich collection of books on his shelves, containing all methods of medicinal prescriptions and tools and utensils. There are two volumes of secret books, which are specialized on the method of smelting yellow [gold] and white [silver] (lian huang bai zhi shu 煉黄白之術). Grand Secretary Chen Mingxia (courtesy name Baishi) from Liyang wanted it to be imparted, but was unsuccessful. ${ }^{9}$

The term lian huang bai zhi shu usually refers to the artificial creation of spiritual or actual gold and silver in an alchemical context. It appears likely, though, that the volumes the guest is referring to are indeed books about Western mining, smelting, and assaying technology, a field of knowledge which may have aroused no less curiosity than the former. At any rate, Schall must have had access to relevant Western literature beyond Agricola's De re metallica alone. Determining which works these may have been is a first necessary step in the search for the sources of the KYGZ.

\section{Western mining books in Ming China}

The largest delivery of Western books to reach China before the compilation of the KYGZ in the 1630s was without doubt the one shipped by Johann Schreck (1576-1630) and Nicolas Trigault (1577-1628) from Lisbon to Macau in 1619. After a systematic book acquisition tour through Europe, which was mainly led by Schreck (Golvers 2012, 202214), about 7000 volumes were shipped (Golvers 2013, 74; Mao 2006, 10-15), covering besides-obviously-religious topics a vast range of fields of European science and technology expected useful for the aims of the Jesuit Mission in the years to come. The largest surviving share of these books included those for the Nantang 南堂 (lit. "South Church") in Beijing, where Schall lived and worked during the last years of the Ming period. These books are today a part of the Beitang 北堂 (lit. "North Church") collection in the National Library of China (Zhao 2015), and can generally be identified through a missionis sinensis inscription as part of the "Schreck-Trigault layer" (Golvers 2013, 107-112). ${ }^{10}$ The catalogue of the Beitang collection (Verhaeren 1949) reveals that among these books were several treating topics of relevance to Schall's and Li's KYGZ project.

9 “湯架上書頗富。醫方器具之法具備。有祕冊二本。專煉黃白之術。溧陽陳百史相國名夏欲傳之 不得也。”

Tan (1960, chapter “Ji wen shang" 紀聞上, 277-278), translation by the author, emphasis added. This visit and Tan's comments on Adam Schall von Bell are described in greater detail by Albert Chan (1998, 278-280).

10 These books are usually marked in the Verhaeren catalogue of the Beitang collection as "Bibl. Trig." See Verhaeren (1949). 


\subsection{Georgius Agricola: De re metallica and Vom Bergkwerck}

The most prominent and, at its time, presumably most useful work on mining and metallurgy accessible to Schall was certainly Georgius Agricola's De re Metallica (Agricola 1556), which is listed in the Beitang catalogue as entry \#730 (Verhaeren 1949, 203). Though published as early as 1556, this work, in which the eminent German Renaissance scholar had collected and organized most related knowledge available in Central Europe during his time, remained state of the art throughout the seventeenth century. Due to his systematic approach and the theoretical foundation he provides to his observations, Agricola is widely considered as the "Forefather of Geology" and mining science (Adams 1938, 185; Guntau and Mathé 2013, 90). De re metallica was originally written in Latin, and subdivided into twelve books treating different aspects of mining, assaying, and smelting, and abundantly illustrated with 292 finely worked woodblock prints.

Due to the presence of a handwritten dedication and an ex-libris in the book preserved in the Beitang collection, we are exceptionally well informed about the circumstances surrounding the acquisition of this volume. ${ }^{11}$ Besides the line missionis sinensis identifying the book as part of the "Schreck-Trigault layer" in the Beitang collection, opposite to the title page a coat of arms is imprinted, into which the initials "M. M." have been written by hand (see Figure 1). Under the coat of arms, a handwritten dedication has been added, which identifies one of its earlier owners as Michael Mändl in Eisendorff, propraetor or unterrichter in Munich. Mändl must have given the book in 1617 as a gift to his friend Georg Locher, syndicus or stadtschreiber in Munich. Locher in turn offered the volume to Johann Schreck, who brought it to China.

The identities of the two previous book owners and their connection can be reconstructed to a certain extent: (Johann) Georg Locher of Ehingen (today state of Baden-Württemberg, then Further Austria) graduated from the University of Ingolstadt as a Doctor of Law in 1590 (Resch and Buzás 1975, 86), and appears as stadtschreiber in Munich at least as early as $1606 .{ }^{12}$ One year later he was elevated to hereditary nobility by Archduke Maximilian III of Austria (von Goldegg 1875, 125). In the year 1612 he held the office of Prefect of the Sodality of the Blessed Virgin Mary ("Marianische Männerkongregation") at the St. Michael's church in Munich, a lay congregation under the jurisdiction of the Jesuit order. ${ }^{13}$ It may be through this connection that he became

11 For this reason, this De re metallica volume has been treated as an example by Noël Golvers and Zhao Daying in their respective works (Golvers 2012, 35; Zhao 2015, 255).

12 Bayerisches Hauptstaatsarchiv, Signature StAM, Toerring-Jettenbach (II, 7) 979 “Anna, Witwe des Schäfflers + Ruprecht Jaus, Mitbürgers zu München; S: Stadt München (Grundsiegel, das die ehrenfesten Dr. jur. utr. Georg Locher, Stadtschreiber zu München, und Michael Männdl, Unterrichter ebenda, als hierzu Verordnete angehangen haben.)."

13 Website of the Marianische Männerkongregation Mariä Verkündigung am Bürgersaal zu München. 
involved with Schreck and Trigault during their visit four years later. Locher had then just completed the most important work of his life, the Codex Maximilianus (Maximilian I. 1616), a new law code for the state of Bavaria, which he compiled together with Chancellor Johann Gailkirchner and the Jesuit pater Simon Wangnereck. ${ }^{14}$

It appears that the ex-libris showing a coat of arms with mandolins among other musical instruments included belonged to the family of the other owner, Michael Mändl, and that "M. M." are his initials (Golvers 2012, 35).15 Sometime before 1616 an undated archival entry was added in the Munich State Archive indicating that he purchased a large property that included the village of Eisendorf and a brewery. ${ }^{16}$ Thus, it seems that Mändl was not only active as an official in Munich, but operated his own businesses beyond the city. His acquisition of De re metallica around this time may, therefore, have been related to possible expectations concerning the existence of iron deposits on his new property in Eisendorf (lit. "iron village") as well-surely a vain hope, because the term Eisen in the village name dates back to a historical person named Iso, which is testified in the region in $825 .{ }^{17}$ In the catalogues of the Munich State Archive, many documents from the years under consideration are jointly signed and sealed by "Mändl, Unterrichter" and "Locher, Stadtschreiber" (Schulze 1996, 286). From this it can be concluded that the two must have been working together for a considerable period of time. What is more, it can be found that in 1623 the city council decided on a case concerning both of their sons together in one session (Stahleder 2005, 388).

Schreck visited Munich twice, once briefly around August 8, 1616, and again for a somewhat longer time between May and September 1617. It must thus have been on the second visit that Johann Georg Locher gave the book to him; on the first visit, however, Schreck may have already expressed his interest in De re metallica in

Accessed June 10, 2020. https://www.mmkbuergersaal.de/ueber-uns/geschichte/verzeichnisder-praefekten.html.

14 The stadtschreiber in Munich Johann Georg Locher of Ehingen is not to be confused with the astronomer Johann Georg Locher of Munich, who graduated from the University of Ingolstadt as a Doctor of Law in 1617 (Resch and Buzás 1975, 89), and was, especially through his supervisor Christoph Scheiner (1573-1650), closely linked to the Jesuits (one copy of his dissertation was even part of the Trigault layer in the Beitang Library, Verhaeren [1949, \#2685]). I thank Hans Ulrich Vogel for clarification on this point.

15 Warnecke includes an ex-libris description matching the one under consideration under the entry "Mandl von Deutenhofen," another branch of Mändl's family (Warnecke 1890, 124) "Das von einer Randleiste von Musikinstrumenten umgeben Wappen mit einem Helm über leerer Schrifttafel" [Coat of Arms with a Helmet above Empty Tablet Surrounded by a Margin of Musical Instruments].

16 Bayerisches Hauptstaatsarchiv, Signature StAM, Toerring-Jettenbach C 9 “Die von Dr. Mändl zu München um $23000 \mathrm{fl}$ erkaufte Hofmark Eisendorf und die Behausung und das Bräuhaus zu Grafing. Mit Originalkaufbriefen, Quittungen."

17 Personal communication with Bernhard Schäfer, head archivist of the Grafing municipal archive, December 17, 2017. 
particular, or in the genre of mining and metallurgy in general. Since the inscription says that Michael Mändl gave the book to Locher in 1617, this can only have been a few months before Schreck visited the second time, and it should thus be assumed that Mändl gave it to Locher already with the purpose of donating it to Schreck. Besides the

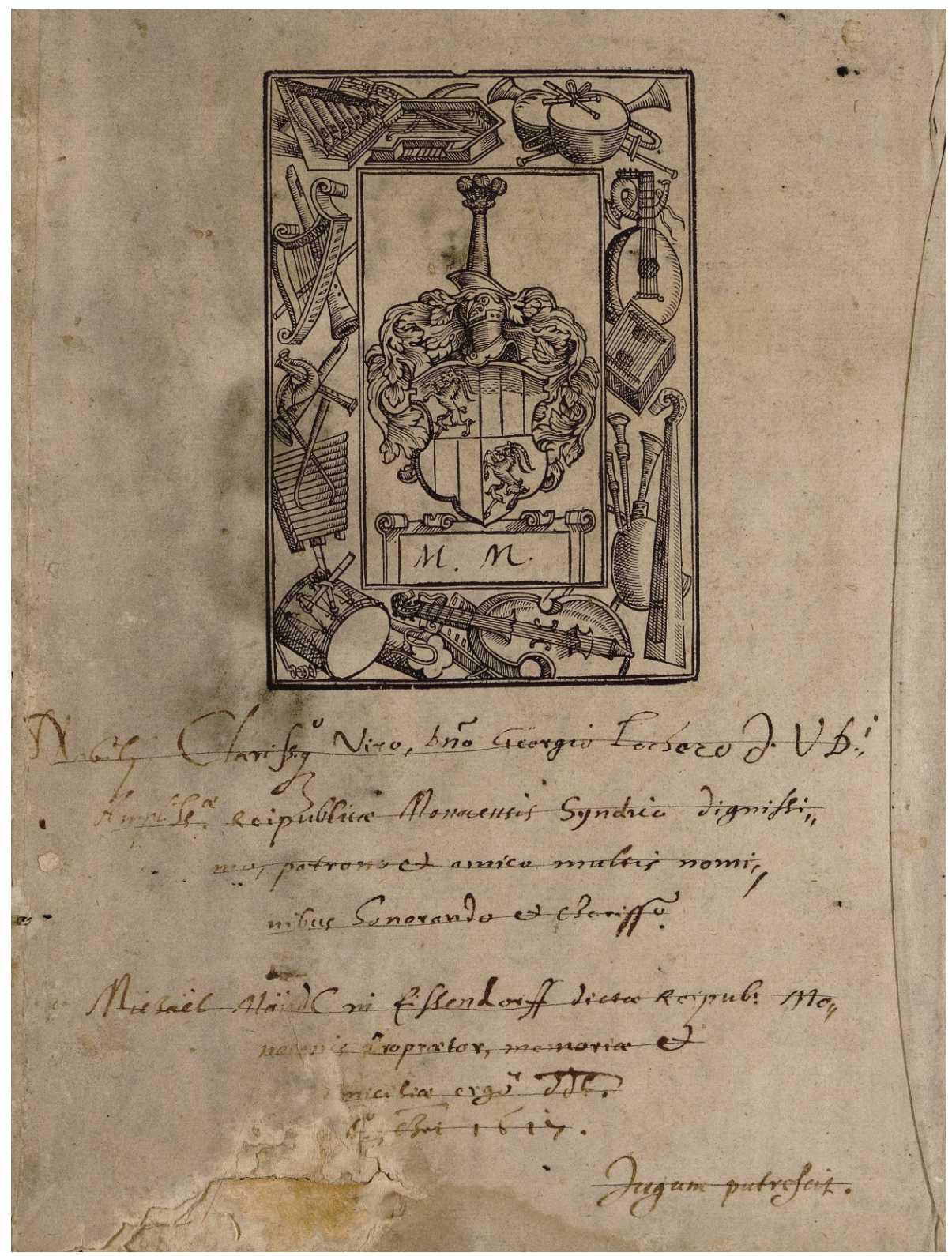

Figure 1: De re metallica volume from the Beitang collection kept by the National Library of China, part of page with dedications by Georg Locher and Michael Mändl as well as coat of arms and Mändl's initials. Courtesy of the National Library of China. 
dedication and the ex-libris, the book in the Beitang collection also contains a great number of annotations mainly concluding the paragraphs beside them, different kinds of changes and manipulations of illustrations, as well as glue stains indicating that tracing paper was fixed above them in order to facilitate copying.

It is very likely that besides this volume, Schreck and Trigault brought another version of Agricola's book to China as well. On a list of books purchased by them in December 1616 in Antwerp, which is preserved at the Museum Plantin Moretus (Golvers 2018, 165-199), the entry for item 79 out of 331 reads " 1 Berghwerck Buch Agricola f Francf $8^{\circ}$ fl. 4 st -." Berckwerck Buch is the title to the octavo second edition of the German translation of Agricola's De re metallica by Phillippus Bechius (1521-1560), which was in fact published in Frankfurt in 1580 (Golvers 2018, 175; Agricola and Bechius 1580). With a price of four Gulden (guilders) it appears to be among the most expensive books Schreck and Trigault purchased in Antwerp, a circumstance surely justified by its size and the richness of its illustrations.

\subsection{Other relevant books available in Beijing}

Besides De re metallica, the Beitang catalogue contains a number of books either entirely concentrating on metal production, or at least containing knowledge relevant to this topic among other fields. Most of them had reached Beijing before the compilation of the KYGZ.

One is a small volume in which two shorter works in German have been bound together. The first of these shorter works is Probierbüchlein (Fachs 1595; Sisco and Smith 1949; Verhaeren 1949, 1132, \#3910), a practitioner's guide to assaying ores and metals compiled in the 1560s by Modestinus Fachs (?-before 1595), Principal Mint Master at Anhalt in Zerbst, and later Mint Warden of Saxony in Leipzig, but published only posthumously 1595 by his son Ludwig (Long 1991, 344). The genre of probierbüchlein or docimastae was very popular and widespread from the fifteenth century, especially in Central Europe (Darmstädter 1926), and Fachs's book, for instance, was re-published several times to meet this demand. The second work in the volume, also published in 1595, is entitled Bergwercks Geschöpff und wunderbare Eigenschafft der Metalsfrüchte (Meyer 1595; Verhaeren 1949, 1147, \#3952) by Georg Meyer (latinized as "Marius," 1533-1606), universal scholar and physician at several German courts, reporting on his experiences during travels in the mining regions of Thuringia and Saxony in the late sixteenth century (Heyers 1957, 43).

In addition to these, other books containing long passages on topics of geography, mineralogy, natural history, and related fields are numerous, and include works such as Hieronymus Cardanus's (1501-1576) De rerum varietate (Cardanus 1557; Verhaeren 
1949, 349, \#1206), Theodor de Bry's (1528-1598) descriptions of the world, ${ }^{18}$ as well as various editions and commentaries of Aristotle's works. Golvers attributes the procurement of further books about minerals by Schreck and Trigault, and thus their availability in the Beitang Library, mainly to the interest of Schreck in their medical use, especially in the context of spas and other water-related treatments (Golvers 2015, 310315).

Like the German version of De re metallica, there were more Western books that had traveled with Schreck, Trigault and other Jesuits to China before 1640, but were not recorded in the Beitang catalogue, because they were kept elsewhere or were subsequently lost. The Plantin Moretus book purchase list contains another highly relevant book, which appears under entry \#63 as " 1 Mineralische Ertzt und Bergwerck theutsch $f^{\circ}$ Francf. fl. 3 st." (Golvers 2018, 174). As will be demonstrated later, it is very likely that this refers to the Beschreibung der allerfürnemsten Mineralischen Erzt und Bergwerksarten by Lazarus Ercker (1528/30-1594) from 1580 (Ercker 1580). ${ }^{19}$ Ercker, like Fachs, was a mint master who had gathered broad technical experience in his position, and later as a mining official in different regions of Germany. After producing a number of minor manuscript writings, likely having been influenced by De re metallica, he concluded his oeuvre with a volume of impressive size and similarly impressive wood engravings, in which he introduced in German the state of the art of assaying and smelting in great detail (Long 2001, 190).

Furthermore, a letter written by Schreck during his book collection tour in 1617 to his friend, the papal physician Johannes Faber (1574-1629) in Rome, contains the words "pro Pyrotechnia, Phytobasano pago gratias multas" [for the Pyrotechnia and the Phytobasanos I pay many thanks to you]. ${ }^{20}$ Thus, most likely, besides the Phytobasanos (Colonna 1592), ${ }^{21}$ Schreck had received a copy of Vanoccio Biringuccio's De la pirotechnia $^{22}$ from Faber. This Italian-language work was first published as early as 1540,

18 Only volume 9 of de Bry's monumental Peregrinationes series is contained in the Beitang catalogue (De Bry 1602; Verhaeren 1949, 322, \#1133). This work, being the ninth and last volume about the American continent, contains Latin translations of travelogues related to the Americas, and therein extensive descriptions about mineral riches and their exploitation.

19 Note that this book was published in the same year, and by the same publisher, as Agricola and Bechius (1580).

20 Letter from Johann Schreck, then in Trigault's hometown Douai, to his friend Johann Faber in Rome on February 24, 1617. The letter is preserved in the Bibliotheca dell' Academia Nazionale dei Lincei e Corsiana in Rome. Filza 415 "Lettere d'interessi diversi scritte al sig.r dottor Giovanni Fabri medico di Bamberga," fo 506r.) My thanks to Noël Golvers for this information.

21 Phytobasanos (lit. "touchstone of plants") was a botanical handbook written by Fabio Colonna, to whom Schreck was connected through his membership of the Accademia dei Lincei (Freeberg 2003).

22 Exactly which edition was sent to Schreck is unknown, the first edition being the one published in Siena 1540 (Biringuccio 1540). A later edition of 1678 is contained in the Beitang catalogue, which of course could not have possibly been used by Schall (Verhaeren 1949, 937, 
and can be counted as the oldest truly comprehensive printed book on the topic of metallurgy in Europe (Biringuccio 1540; Smith and Gnudi 1942). ${ }^{23}$ It includes information about the identification of ores, assaying, smelting, and casting, and was in fact used by Agricola in the compilation of his De re metallica. ${ }^{24}$ With the books of Biringuccio, Agricola, and Ercker to hand, it can thus be considered realistic that during the writing of the KYGZ, Schall had access to the three most comprehensive and important works on mining technology and metallurgy available in Europe during his time. These three standard works were complemented by a modest selection of other writings containing potentially useful information, especially on assaying.

Besides information obtained from these (and other, so far undiscovered,) Western books, the possibility must be considered that Schall had some practical expertise or knowledge in the related fields acquired before his departure from Europe. He grew up in Köln, not far from the Ruhr coal and iron mines. He had enjoyed an excellent education there, and later at the Collegium Germanicum in Rome, which must at least have included mathematics and certain studies of the natural world - though probably not far beyond the Aristotelian canon.

During his time in China, Schall was repeatedly involved with the use and construction of Western style artillery. Upon his arrival in 1622 he presumably operated a cannon on the Macau fortress hill against attacking Dutch ships (Väth 1933, 63-64). In 1642, upon imperial request he personally organized and guided the casting of a greater number of cannons (Väth 1933, 111), and just one year later he worked together with Jiao Xu 焦勋 on the compilation of the Essentials of Fire Assaults (Huogong qieyao 火攻㨻要), an introduction in Chinese to the making and use of European artillery (Schall von Bell [Tang] and Jiao [1643] 2019; Zheng 2019, 365-570). Before Schall was entrusted with the casting task, the Minister of War had approached him inquiring about his knowledge and practical experience in this field. In his memoirs he remarks about this occasion:

I still kept him at bay for a moment, saying that I had learnt about the like in books, not in the field, that I also never even assisted at similar works or even saw the instruments

\#3701). The possible role this Pirotechnia volume may have played in the writing of the Miraculous Weapons of the West (Xifa shenji 西法神機) by Sun Yuanhua 孫元化 in 1632 and other late Ming works on artillery requires further study (Sun 1632; Yin 2009, 381; Zheng 2012, 470).

23 In fact, the printing of the much smaller Nützlich Bergbüchlin by Ulrich Rühlein in 1527, as well as Agricola's Bermannus dialogue of 1530, and the anonymous publication of one similarly short Probierbüchlein (of no direct relation to the one by Modestin Fachs) in 1533 preceded it (Long 2001, 177; Anonymous 1533).

24 Agricola himself writes in his preface to De re metallica: "Recently Vannucci Biringuccio, of Sienna, a wise man experienced in many matters, wrote in vernacular Italian on the subject of the melting, separating, and alloying of metals. ... [B]y reading his directions, I have refreshed my memory of those things which I myself saw in Italy." (Agricola 1556, Epistola 2; Hoover and Hoover 1950, xxvii; Agricola 1974, 30). 
that the cannon casters used.25

It may have been modesty on his part, or the intent to refuse the minister's request to produce deadly and destructive weapons, that motivated Schall's response. However, his reaction also indicates that it was his work for the KYGZ that helped him with the casting of the cannons, rather than vice versa. It is, furthermore, interesting that Schall must have remarked later that during the process of cannon casting, which was of course carried out with refined raw metal, the acquisition of the right charcoal and the regulation of the temperature in the furnace created great difficulties - both issues described in the KYGZ in some detail (KYGZ 2:11a-13b). ${ }^{26}$

\section{The use of Western sources in the compilation process}

With at least the minimum of books realistically available to Schall in China by the late 1630s now clarified, in the following, one representative example passage is analyzed for each of these works that could be clearly identified as sources for the text of the KYGZ. By doing so, proof for the use of each work is given, the different ways in which Schall incorporated them into his Chinese text are shown, and his choices as to which sources to use in which thematic chapters become apparent.

Since the Chinese text of the KYGZ is very extensive (more than 36,000 characters in length), and the source of information cannot be clearly identified for all passages, a complete quantitative survey of its Western sources cannot be attempted here. An analysis of only the textual passages based on De re metallica is not undertaken either, because they make up the vast majority of the text, and the characteristic of this work as a main source has therefore never been in dispute. ${ }^{27}$

For all example passages, the Chinese original text of the KYGZ is given in the left column in a version cleaned of intentionally or unintentionally miswritten characters and with revised punctuation (Vogel 2015, 9). The text of the Western source in its original language (German, Italian, or Latin) is placed in the right column. The central column contains the English translation of the Chinese KYGZ text. ${ }^{28}$ All information in the texts that appears to be a direct translation, or at least closely similar, is marked in grey.

25 "Detinui eum tamen paulisper, dicens me in libris non in castris similia didicisse, imo ne quidem similibus operibus adstitisse vel vidisse ea quibus tormentorum fusores instrumentis utuntur." Translation by the author (Bernard 1942, 83; Väth 1933, 111).

26 A part of this chapter, which is largely based on the Probierbüchlein by Modestinus Fachs, is discussed later in this article. I have not been able to verify Schall's remark about his difficulties from primary sources (Schimmelpfennig 2012).

27 For detailed analyses of those passages related to De re metallica, see the forthcoming publications by Hans Ulrich Vogel and Cao Jin in the context of the DFG research project "Translating Western Science, Technology and Medicine to Late Ming China."

28 For details concerning this translation, see footnote 4 of this article. 


\subsection{Vannoccio Biringuccio on mercury ores}

In the chapter “Verifications of Ore Tenor" (zheng kuang pin fu 徵礦貧富) (KYGZ 1:8a$12 \mathrm{a})$, Biringuccio is the main source of information for passages on the ores of copper, mercury, lead, tin, and iron. The passages on gold and silver contain information from both Agricola and Biringuccio. In the following, the situation for the passage on mercury is shown.

Synopsis 1: KYGZ29 and De la Pirotechnia (Biringuccio 1540, 24b; Sisco and Smith 1949, 82) on mercury

\begin{tabular}{|c|c|c|}
\hline 論水銀, 因其 & mercury, because its nature is & Tutti li monti o luochi doue la si genera \\
\hline 性凉，非復琉 & cold, it is not like sulphur, green alum & son copiosi dacqua \& d'arbori, \\
\hline 黄緑䙪等，能 & and others, which can by themselves & l'herbe vi son verdissime. Perche ha con \\
\hline 自發乾，以傷 & give off dryness by which the $q i$ of & se freschezza, \& non vapora siccita \\
\hline 植物之氣。故 & plants is harmed. Thus, its mountains & come fa il solfo, il vitriolo, el sale, \& \\
\hline 其山多景致水 & scenery with waters and & simili. Ma e ben vero che gli arbori che \\
\hline 泉，草木俱 & springs, and grass and trees are all & vi sonno non producano fiori, \& se gli \\
\hline 茂, 得其本 & luxuriant, getting their original color. & producano non conducono a maturita \\
\hline 色。樹木發葉 & Trees, [however,] grow leaves very & gli frutti. In la prima vera metteno le \\
\hline & late and blossom rarely, and [if so] the & foglie piu tardi che negli altri luochi, \\
\hline 菆，花不結 & ossoms do not bear fruit. & che per la freschezza desso douerrien \\
\hline & rain uses its $\mathrm{V}$ & \\
\hline & it. On a spring day befor & Cognoscesi doue questo sia el mese \\
\hline & one] sees that vapor em & de Aprile, o del Maggio, la mattina \\
\hline & mountain is very thick, [but] does not & auanti il leuar del sole quando li tempi \\
\hline & rise much, then it is a place which has & son tranquilly \& quieti, a certi vapor \\
\hline 投 & ore. When [one] wants to distinguish & grossi \& densi, che sopra a quell luocho \\
\hline 氣 & between good or bad [ore], it is a good & si eleuano, ma per esser graui non \\
\hline 揚起， & formidable tenor] if & arriuano molto in alto, \& alcuni che \\
\hline 之地。欲識其 & generally the direction in which the & hanno di tal cosa isperientia, vallo per \\
\hline 佳惡, 大約脉 & vein enters the earth leads & tal segnale, come si fa del lacquer quasi \\
\hline 入土向北行為 & northwards. & apposta a trouarlo, \& dicano che se tal \\
\hline 佳兆。 & If stones of second-rate red are & e volta verso \\
\hline 若內生次 & produced inside [of a vein], which are & settentrionale eser perfettissima. \\
\hline 紅石, 與硃砂 & of no difference to cinnabar, they & Generasi questo comunemente in \\
\hline 無異。畫開碎 & open up tiny holes everywhere, and & vna pietra biancha mortigna, o vero in \\
\hline 孔, 孔中載水 & in the holes mercury is carried, which & vnaltra biancha simile a vna calcine, \& \\
\hline 銀，成滑體， & forms slippery bodies like water & anchorea sene troua molte volte in un \\
\hline 如水點。點愈 & drops. The more drops there are, the & scuro quasi come vn \\
\hline 多、脉愈富 & richer the vein. & tute conise \\
\hline
\end{tabular}

29 KYGZ (1:10b-11a). Translation: Jost (trans.), Vogel, Cao \& Kink (rev. \& ed.). 


\begin{tabular}{|c|c|c|}
\hline 矣。若無此, & [stones], but [one] encounters instead & spognoso, neliquali buseti di spognosita \\
\hline 反遇青色或藕 & blue-green-colored or pale pinkish & visi genera come goccioline proprie \\
\hline 合色之斑點, & purple spots, then the ore for sure is & dacqua. Delquale quanto piu vi sene \\
\hline \multirow[t]{5}{*}{ 其礦必貧。 } & \multirow[t]{5}{*}{ poor. } & vede infra essa, tanto e la miniera \\
\hline & & migliore, \& se in detta \\
\hline & & appariranno \\
\hline & & alquanto bigie, ouero azure sara la \\
\hline & & miniera magra. \\
\hline
\end{tabular}

The reason why Schall decided not to rely on Agricola for his passage on the ores of mercury as well as other semi-precious and base metals is simply that these topics are only treated very briefly in De re metallica (Agricola 1556, 76; Hoover and Hoover 1950, 107; Agricola 1974, 131), and little further information on their environments and the contexts of their appearance is provided. Since Biringuccio is more thorough here, using passages based on his book seems reasonable.

As to the method of incorporating information from the Italian original into the Chinese text, it can be concluded that the text is translated almost word by word as far as it can yield an acceptable and understandable result in Chinese. The few words in the KYGZ that have no Italian equivalent are simple complements to the content of the text, which do not require further knowledge. In the opposite direction, likewise some short omissions can be noticed, but nothing that changes the meaning to any extent. The reasons for Schall to remain so close to the text may have been that the recognition of mercury-bearing ores was a field entirely beyond his own experience, and he had no alternative sources, illustrations, samples, or the like to rely on.

\subsection{Modestinus Fachs on fire control}

One rather extensive example for the use of Probierbüchlein can be found in the chapter entitled "General Method of Assaying Gold and Silver" (Jin yin gong shifa 金銀公試法) (KYGZ 2a:11a-13b). After describing the extraction of gold and silver from their ore by means of amalgamation with lead, the text continues to explain how the strength of the fire in the assay furnace could be controlled in order to allow sufficient temperatures for the precious metals to liquefy, but at the same time how to prevent excessively high temperatures, which would result in the evaporation of lead before the formation of an amalgam. The example below is the central part of this passage: 


\section{Synopsis 2: KYGZ30 and Probierbüchlein (Fachs 1595, 8-10) on fire control}

\begin{tabular}{|c|c|c|}
\hline 欲用大火，其炭 & vishes to have a big fire, then & Aber lauter messige Kohlen / als \\
\hline 宜中等，約不及 & the charcoal should be of middle & ungefehrlich die halben Eyer groß / \\
\hline 雞蛋大者是。 & to have & fleissigem \\
\hline 欲更大其 & approximately a size not as big as & probieren. [...] \\
\hline 火，必多開灰 & hen eggs. If one wants to make the & Wenn du den Ofen heiß treiben \\
\hline 門，去礶盖上 & fire even larger, one must open the & willst / so wirf lautere rechtmessig \\
\hline 灰，并去碎炭。 & ash gate [more] often, remove the & grosse Kohlen darauff. / lege in das \\
\hline & ash above the crucible's cover, and & obere Mundloch eine Kohle / und thue \\
\hline 之, 始得。若火 & remove charcoal fragments. One & das unter Mundloch auff / unnd \\
\hline 門中加大炭一 & only can obtain & reume mit einem Hecklein von der \\
\hline 塊, 其火力愈 & vledgeable & und Bodenbletlein / die \\
\hline & $\begin{array}{l}\text { people regulate it. If one puts an } \\
\text { additional piece of big charcoal into }\end{array}$ & $\begin{array}{l}\text { kleinen Kohle unn Aschen / und laß } \\
\text { derselben messig unten am Boden }\end{array}$ \\
\hline & the fire gate, the strength of its fire & liegen / so treibet der Ofen lauter unn \\
\hline & increases even more. If one [now] in & \\
\hline & ce it & So du aber den probier Ofen wider \\
\hline 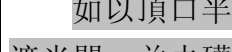 & accordance with & gemachsam wilt warm haben / so thue \\
\hline 遮半開, 并去礶 & as [its & ihm also / scheibe oben den Deckel \\
\hline 盖口之前板, 此 & proper] sequence. Having the vertex & zurück / das der Ofen halb offen wird \\
\hline & mouth half-covered half-opened & / desgleichen das ober Vorschieblein \\
\hline & and, moreover, th & eb auch wegk. \\
\hline 口板，復上前口 & orifice of the & 1 kalt / so thu \\
\hline 板，而止令 & removed, this is the first & hintere Instrumentlein heraus / unnd \\
\hline 閉合，二十 & remove & scheube das halb ausgeschnittene \\
\hline 次以大開礶盖之 & the back-orifice board of the same & Vorschieblein wider für. Will er dir \\
\hline & cover and to place back the front- & noch zu kalt gehen / so hebe die seiten \\
\hline 更以畫 & orifice board without having it & Instrumentlein auch heraus. Gehet er \\
\hline 盖，而于前， & closed, & hebe den Deckel gar \\
\hline 靠炭三塊, 以代 & second [step]. The next is to open up & vom Ofen weg / unn scheub das halb \\
\hline 換其門板，四 & widely [all] the holes of the crucible & ausgeschnittene Instrumentlein auff / \\
\hline & cover, which is & unnd lege ein par Kohlen inn das \\
\hline 末乃畫 & When going even further, one & Mundloch / \\
\hline 椚及礶盖左 & oves completely the [furnace & gemachsam wider warm. Wenn du nu \\
\hline 諸小盖, & vertex cover and leans up three & letzlich den Ofen gar wilt wider warm \\
\hline 令周圍進風, 即 & pieces of charcoal at the fire-gate in & so thue das unter \\
\hline & furnace] & auch weg / so gehet er \\
\hline & ich & wic \\
\hline 于火門內 & $\left.e^{\prime} s\right]$ & It haben willst / so thue im \\
\hline 月炭。 & below a & \\
\hline
\end{tabular}

30 KYGZ (2a:12a-13a). Translation: Cao (trans.), Vogel \& Kink (rev. \& ed.). 


\begin{tabular}{|c|c|c|}
\hline $\begin{array}{l}\text { 以 頂 盖似閉 非 } \\
\text { 閉, 獨小縫約 } \\
\text { 三四分。 } \\
\text { 又次則塞其 } \\
\text { 灰門, 再塞礶盖 } \\
\text { 之後及左右之諸 } \\
\text { 孔, 得火極微。 } \\
\text { 若更將火門 } \\
\text { 略閉, 即庶幾凉 } \\
\text { 其火矣。 }\end{array}$ & $\begin{array}{l}\text { small covers of the left and right } \\
\text { holes of the crucible cover to let } \\
\text { wind come in from all around, } \\
\text { which is then top fire. } \\
\text { If, on the contrary, one wishes to } \\
\text { reduce the strength of the fire, the } \\
\text { first [step] is to use no charcoal at all } \\
\text { inside the fire gate. The next [and } \\
\text { second step] is to leave the } \\
\text { [furnace's] vertex mouth seemingly } \\
\text { closed, but not completely so, as one } \\
\text { leaves [open] a small seam of only } \\
\text { about } 3 \text { to } 4 \text { fen. The next [and third } \\
\text { step] is to plug the ash gate and also } \\
\text { to plug the back, left, and right holes } \\
\text { of the crucible cover, [thus] } \\
\text { achieving that the fire becomes very } \\
\text { small. When going even further by } \\
\text { almost closing the [furnace's] fire } \\
\text { gate, then the fire will be almost } \\
\text { cooled down. }\end{array}$ & $\begin{array}{l}\text { mundloch / darnach so lege den } \\
\text { Deckel oben auff den Ofen / doch dass } \\
\text { das Fewer etwan ein zwerich Finger } \\
\text { lufft behelt / darnach scheub das unter } \\
\text { Vorschüblein für / so merckest du / } \\
\text { das der Ofen allbereit umb viel kälter } \\
\text { gehet. } \\
\text { Wilt du ihn noch kelter haben / so } \\
\text { setze das halb rundt Instrumentlein } \\
\text { hinten für / das Loch der Muffel / auff } \\
\text { beiden seiten die andern zwey / unnd } \\
\text { scheub das halb ausgeschnittene } \\
\text { Vorschieblein auch für / so wird } \\
\text { alsdenn der Ofen so trübe / das die } \\
\text { Muffel unnd Capellen / so darinnen } \\
\text { seind / ganz schwartzbletzig werden. }\end{array}$ \\
\hline
\end{tabular}

Similar to the Biringuccio example, the reason for Schall to select the Probierbüchlein as a source for this topic may have been that although the lead amalgamation process and methods of fire control are described in other texts as well, none of them lists as many individual steps as the Probierbüchlein, or provides as many details about the control measures.

It is, however, obvious that the insertions to complement the Chinese text are more numerous than for the Biringuccio sample passage above, especially the numbering of the different steps, which is not part of the German text. Sentences that are new are of a very general instructive tone, such as "One only can obtain [the right strength of the fire] by having knowledgeable people regulate it" or "If one [now] in general wants to increase or reduce it in accordance with the [required] standards, then this all has [its proper] sequence." The reasons for such insertions may be that Schall and his collaborators considered the oral style and somewhat negligent sentence structure of the Probierbüchlein as inappropriate for a treatise that should - all useful aspects asidereflect the superiority of Western science to Chinese elites. The emphasis on "knowledgeable people" operating a "proper sequence" according to "required standards" may have served the purpose of increasing the impression of the serious and systematic character of the information conveyed. All in all, omissions of technical content of the German version in the Chinese rendering are rather more as well. This 
may be due to the fact that the information in this passage is to a much larger extent "common sense" than, for instance, the identification of mercury ores. Anyone who has used an oven for heating or cooking, or observed the work of a blacksmith changing a horseshoe, will generally understand the relation between fresh air supply and fire strength, just not to the same level of sophistication as Mint Master Fachs. ${ }^{31}$

\subsection{Lazarus Ercker on the construction of a distillation furnace}

Instances of the use of passages from Ercker's book are more numerous. One of the most complex examples is the construction of a large distillation furnace with several sub-furnaces, known as Fauler Heinz in German. Other terms in use are "tower furnace" or "athanor." 32 Schall introduces this kind of furnace for the purpose of distilling nitric acid, which he calls "strong liquid" (qiangshui 強水), from the common Latin term aqua fortis. 33 Accordingly, the passage appears in the chapter "Methods with Strong Liquids" (Qiangshui fa 強水法) of the KYGZ (2b:10b-16b). A notable characteristic of it is that not only textual information from Ercker is used, but also an illustration from his book is referred to in a descriptive legend preserved in the KYGZ, indicating that Schall most likely planned to include it (see Figure 2).

\section{Synopsis 3: KYGZ ${ }^{34}$ and Beschreibung der Allerfürnemsten Mineralischen Erzt und} Bergwerksarten (Ercker 1580, 64) on the construction of a distillation furnace

\begin{tabular}{|c|c|c|}
\hline $\begin{array}{l}\text { 若圓爐, 則以 } \\
\text { 磚砌, 從底至 } \\
\text { 頂, 約高四 } \\
\text { 尺, 擴一尺三 } \\
\text { 四寸。爐底左 } \\
\text { 右各開一大 } \\
\text { 口, 寬五六 } \\
\text { 寸, 高八寸。 } \\
\text { 爐頂用盖, 準 } \\
\text { 合周邊, 使能 } \\
\text { 移動, 以便隨 }\end{array}$ & $\begin{array}{l}\text { As to a round furnace, one uses bricks } \\
\text { to build it, from the bottom to the top } \\
\text { about four chi high and one chi and } \\
\text { three to four cun wide. At the bottom of } \\
\text { the furnace to the left and to the right } \\
\text { one opens one large orifice each side, } \\
\text { five to six cun wide and eight cun high. } \\
\text { On the top of the furnace one uses a } \\
\text { cover fitting exactly the rim of the } \\
\text { circumference, and in such a way that it } \\
\text { can be moved so that opening and } \\
\text { closing of its upper orifice is facilitated }\end{array}$ & $\begin{array}{l}\text { Mache einen Thurn in die gevire oder } \\
\text { runde } 4 \text {. elen hoch / unnd unten ein } \\
\text { Eysern rost darein / unter welchen } \\
\text { ein windtloch sey / nach der } \\
\text { Proportion der gesatzten Figur / } \\
\text { unndann mache auff beide seiten deß } \\
\text { Thurns wider in gleicher weitten / } \\
\text { nach deines Kruges oder glaß kolben } \\
\text { höhe / runde oder gevierte öfen / } \\
\text { darinnen die gläser oder krüg stehen } \\
\text { müssen / lege auch unten wie im } \\
\text { Thurn oder Heintzen eysserne röste / }\end{array}$ \\
\hline
\end{tabular}

31 Two years later, Schall in fact encountered difficulties with the control of the furnace fire during cannon casting (Schimmelpfennig 2012).

32 From Arabic at-Tannür, i.e. "furnace" or "pipe," which points to its origins in Arabic alchemy (Williams 1956, 743).

33 The term qiangshuifa is already used earlier by $\mathrm{Xu}$ Guangqi with the same meaning in his hand-written notes as well as his Kaicheng jiyao (Xu 1962b, 49-53; Xu 1857, 3b-4a; Gong 2017, 59). The content included in these works is, however, much less detailed, and clearly neither based on Ercker's book nor related to the content of the KYGZ.

34 KYGZ (2b:11a-11b). Translation: Jost (trans.), Vogel, Cao \& Kink (rev. \& ed.). 


\begin{tabular}{|c|c|c|}
\hline 時開合其上口 & by it at any time. One connects the two & also daß es darunter windtlöcher hab. \\
\hline 焉。爐下左右 & 5 at the bottom & In solche neben öfen sollen auß dem \\
\hline 兩口，相連更 & furnace & höhern Thurn löcher gelassen werden \\
\hline 作小爐，其形 & small furnaces. Their shape is round as & / daß die hitz / wie du hören wirst / \\
\hline 亦圓，而身之 & well, and their body sizes take the & auß denselbigen darein gehen kann / \\
\hline 大小以能容料 & capacity to be able to hold a material & welche wann sie ein gute spannen / \\
\hline 礶于内為度。 & vessel inside as a measure. One must & unnd vier finger weit / und eine \\
\hline 但其旁緊貼大 & open a fire orifice at the place where [a & forder spann hoch seind / so seind sie \\
\hline & ched to the & weidt unn hoch genug. [...] \\
\hline 火口, 與大爐 & large furnace, which i & Darnach laß dir $\mathrm{zu}$ solchen \\
\hline 之口等, 乃為 & the & löchern dardurch die hitz ge \\
\hline 通火達礶之 & furnace, which then & Register oder Instrumenta von \\
\hline & the $f$ & Töpfferzeug machen / mit denen du \\
\hline 㤬。成屌 & [in the small furnace]. On & das fewer regiren / fürschieben und \\
\hline 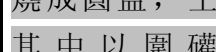 & is a round cover made from burnt & auffschieben kan \\
\hline & earth, wh & [. . .] Ferner muß man auch zu \\
\hline 脛。 & that it thus embraces the neck of the & jedem neben ofen / darein man die \\
\hline & vessel. Therefore, in front and back of & krüg oder die glaßkolben \\
\hline & the rim on top of each furnace, there & zeug setzt / deckel haben / \\
\hline 便于不時啟 & are made small holes, which are & erden oder Toepffer thon gemacht / \\
\hline 塞, 以言 & convenient for opening and closing at & welche also auß geschnitten sein soln \\
\hline 也。且大 & any time and thus for regulating the & / daß sie sich umb den halß deß \\
\hline 爐之中， & fire phase. Moreover, between one & krugs / oder glaß kolbens fein \\
\hline 平薄瓦板, 能 & large and one small furnace one hangs & schlisen / und die öfen auffs gehebste \\
\hline 使上下游移， & up a flat thin clay board that can be & zugemacht können werden / unnd \\
\hline 緊居其間，亦 & moved up and down and rests tightly & lest lufftlöcher dardurch / so man \\
\hline 為調火而設, & between them, which are installed also & ventil nennt / diedo Thännen stöpssel \\
\hline 以畫 & for regulating the fire so that & haben / die geheb nein gehen das \\
\hline 三 爐正面之 & exhaustive use can be ma & $\mathrm{zu}$ regieren $[$. \\
\hline 下， & each of the three & Deßgleichen sol auff dem Thurn eine \\
\hline 及灰門, 內置 & furnaces a & stürtze oder deckel gesetzt wer \\
\hline 鉄床，如楞相 & & sey / daß er deß Thurns \\
\hline 隔, & the & loch oben gar bedecke. Damit ist also \\
\hline 等， & & \\
\hline 製畢矣。 & ace. Herewith the construction of a & \\
\hline & & \\
\hline
\end{tabular}

This description is only included at this level of detail in Ercker's work, not in the other sources available to Schall. It is, moreover, evident that this passage of the KYGZ not only is composed of close direct translations from Ercker's text, but also contains much supplementary information not included there. The reason for this seems to be that, 
besides planning to include the illustration into the printed edition of the KYGZ, Schall and his collaborators used it as a source for their description in the Chinese text. The additional sentences thus do not introduce entirely new topics, and also do not contradict Ercker's text, but merely clarify aspects of the construction of the furnace the latter does not mention explicitly.

The way Schall treats the measurements for the size of the furnace deserves special attention: Firstly, Ercker suggests building a round or square-shaped furnace with a height of four ells, but does not mention any other length measurements. Schall, however, to match the illustration and in order not to confuse the reader, ignores the option of a square furnace, but provides three more additional measures for the round version that can only be taken from the illustration. Furthermore, he directly translates the German elle, which for instance in Saxony during Ercker's time would have measured around 56 centimeters (Gyllenbok 2018, 1276), and in other parts of Germany even above 80 centimeters, to the Chinese chi 尺, a length measure equivalent to 32 centimeters in Ming China (Qiu, Qiu, and Yang 1998, 447). He thus erroneously advises his Chinese reader to build a furnace with a height of about 1.2 meters instead of the about 2.2 meters suggested by Ercker (which also matches the size in comparison to the man in the illustration of Figure 2).

As for the paragraphs chosen for translation in Ercker's text, with only very small exceptions all information is translated or otherwise included in the KYGZ. Any omissions are not crucial parts of the content. Like in many other instances of descriptions taken from De re metallica, the example passage is followed by a detailed legend accompanying the illustration, in which one character of the ten "heavenly stems" (tiangan 天干) is attached to all important items. Crucial information for the understanding of the illustration is repeated (see Figure 2).

This all is shown in illustration .Jia 甲 is a large round furnace, which inside is filled with burning charcoal. Small holes are opened on top for dispelling fire suppressants. To the left and right, the flat thin earthenware boards (waban 瓦板) that are hung up there can be freely moved up and down in the interspaces, like $y \boldsymbol{i}$ 乙. Its cover ( $g a i$ 盖) [looks] like bing 丙. The small furnaces at the sides are like ding 丁, sometimes one furnace, sometimes two or three furnaces, so as to share the benefit of one fire, and thus obtain more liquids. Their furnace covers [look] like $w u$ 戊. As soon as a vessel is lowered into a furnace, it is covered at once. The shape of a square double-furnace (fangshuanglu 方隻爐) [looks] like $j i$ 己. Its horizontally inserted fire-regulating board is like ren 壬, while the cover on top is the same as [described] before. A square single-furnace (danfanglu 单方爐) [looks] like $x$ in 辛. On top there is no cover, but below one more iron bed is added. However, this furnace does not have [the same kind of] material vessel as is concealed in each [of the other] furnaces, where it reaches down to the fire gates and is fitted with a helmet [on top], as [shown by] geng 庚. Instead, its material vessel is entirely concealed 
inside the furnace, like gui 癸. It is only that a spout (zui 嘴) protrudes from the vessel side to the outside of the furnace, and there enters into the jar (tan 墁) for collecting the distillate. ${ }^{35}$
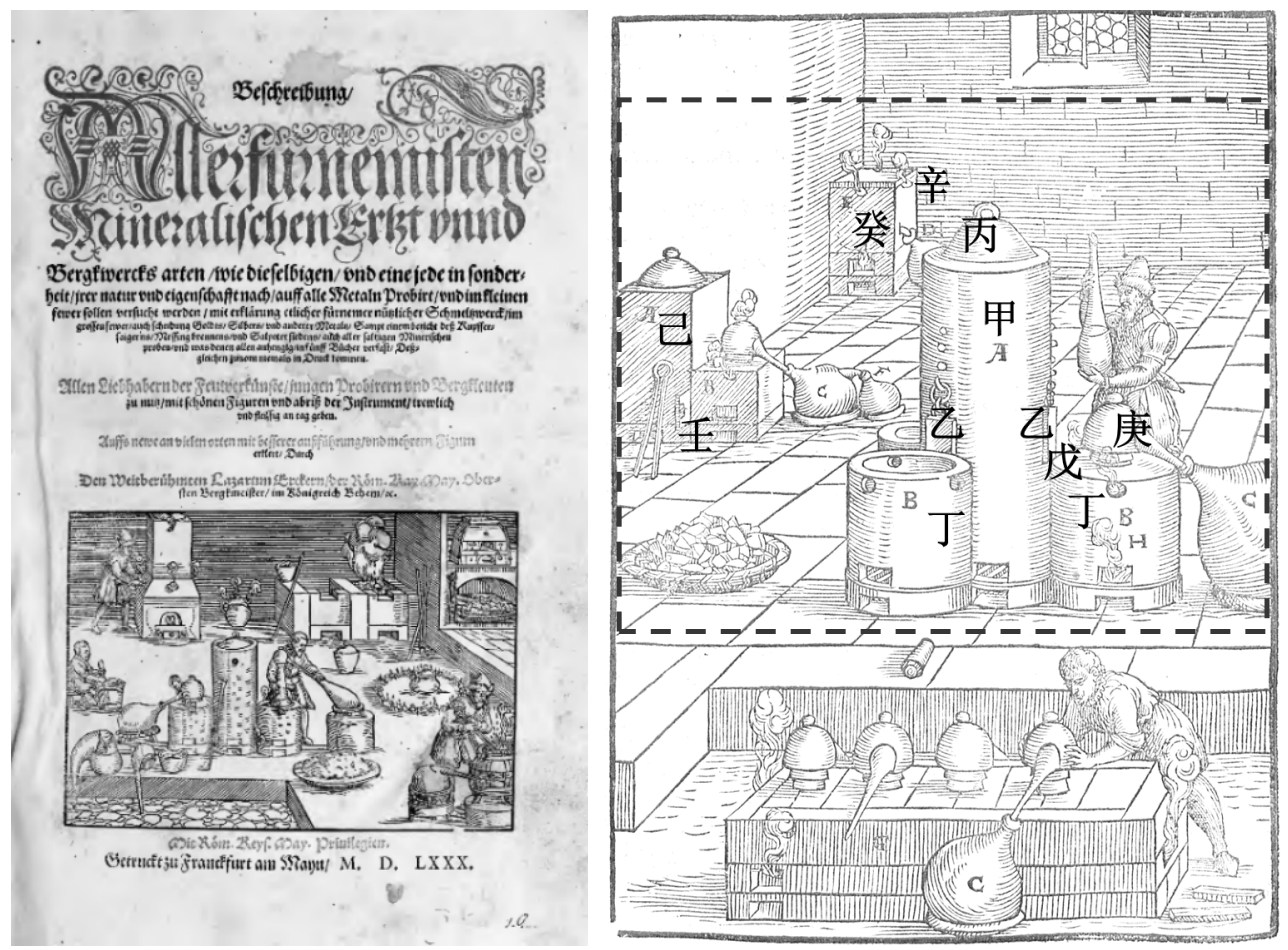

Figure 2: Title page of the 1580 edition of Ercker's Beschreibung der Allerfürnemisten Mineralischen Ertzt unnd Bergkwerksarten and illustration on p. 71 of this book. ${ }^{36}$

It is noteworthy that at the beginning of the paragraph in the manuscript discovered in Nanjing, space for the numeric or other identification of the illustration is left open intentionally. The reason could be that it was not based on a completed version with numbered illustrations included (if one ever existed, as the Nanjing manuscript includes no major illustrations, only a few sketches), but rather on a manuscript reflecting an earlier stage of production.

35 “皆顯于 圖。甲為大圓爐, 內充滿其炭火, 上面開小孔以散火悶。左右所挂平薄瓦板, 隨可 上下其間者如乙。其盖如丙。旁之小爐如丁, 或一爐, 或二三爐, 以共借一火之利, 并得水愈多 故。其爐之盖如成。俟礶下爐內, 當即盖之。方雙爐之形如己, 其調火横進之板如壬, 其上盖與前 同。单方爐如辛, 上無盖而下更加鉄床一層。然各爐內所藏料礶, 則下抵火門, 合之盔如庚, 而此 爐無之, 且料礶全藏爐內如癸, 獨礶旁出嘴于爐外, 而嘴進收露之嚗焉。”

KYGZ (2b:13a-13b). Emphasis added. Translation: Jost (trans.), Vogel, Cao \& Kink (rev. \& ed.).

36 The dashed line describes the field likely to be included in the print version of the KYGZ, while the characters that are added by the author show the legends preserved in the KYGZ and quoted below in this article. The legends have no obvious relation to the legends in Latin characters provided by Ercker. 


\subsection{José d'Acosta and Theodore de Bry on Potosí}

In the chapter entitled "Mining Ore" (Cai kuang 採礦) (KYGZ 3a:21b-25b), Schall discusses the different ways to deal with rock and ore of different hardness, including the sophisticated application of tools and the method of fire-setting. He also describes what methods of excavation need to be applied for deposits of different shapes. All this appears to be more or less directly translated or concluded from the related passages in De re metallica.

Thereafter, however, a paragraph follows that seems to have very little connection to the rest of the chapter. An unnamed silver mine in the "Extreme West" (jixi 極西) is introduced, one that is has already been operating very productively for more than ninety years. The passage continues as follows:

Synopsis 4: KYGZ37 and Historia natural y moral de las Indias in De Bry's Latin translation (De Bry 1602, 142, 147-149).

\begin{tabular}{|c|c|c|}
\hline & mountain & Montanae terrae natiuus color, subrubeus est, tincti \\
\hline 里, & approximately ten $l i$ wide at & aut pyramidati \\
\hline 頂, 形圓色 & its foot and becomes & longinquo exhibens. [. . .] Radix autem milliaris \\
\hline & increasingly & vnius latitudinem habet. [. . .] Sed vniuersae hae in \\
\hline 東正 & towards the top; its shape is & montis parte Orientali constitutae sunt. Versus \\
\hline 北有深脉， & round and its color red. At & occasum, solum venarum similium omnino sterile \\
\hline 脉旁二石，彼 & some distance from the top & est. Venas autem Orientales versus aquilonem \& \\
\hline 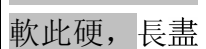 & towards the east in a & austrum exporriguntur, a polo vno ad alterum \\
\hline & south-north & e: quae quo loco diffusissimae su \\
\hline 一尺，多止六 & direction there is a deep & m: quo vero angustissimae, spithamae vnius \\
\hline & vein. At the sides of the & lati \\
\hline & vein there are two [types of] & \\
\hline & rock, one soft, the & reperiuntur. [. \\
\hline & hard. Its length extends & aquilonemque spectant, e supernis deo \\
\hline & through the whole & vergant, tum certe ductus eorum vsq; ad radices \\
\hline & mountain; it is about one chi & montis prosequi oportet: quae profunditas, vt \\
\hline & thick, often up to six chi, & autumant nonnulli, 1200 aestados seu orgias hal \\
\hline 用利器碎之, & ght to the bottc & Irum ea profunditas \\
\hline 不 & $\mathrm{n}$ it is 600 zhang & spatium tamen in circuitu sextuple maius \\
\hline & Today about one part & ambiendum est, priusquam ad ipsam montis basim \\
\hline & out of six he & $m$ diuitijs ingentibus \\
\hline 與出井 & {$[\ldots]$} & de minerarum omnium principijs notum sid, \\
\hline & When extracting & praedicant. [. . .] Minerae, quibus, vt dictum est, \\
\hline & ore], one must make $u$ & argentum promitur, plerunq; intra duos scopulos, \\
\hline 雙梯, 間十 & sharp tools to smash it, day & Casse nominatos, procurrunt: quorum alter \\
\hline
\end{tabular}

37 KYGZ (3a:24a-25a). Translation: Jost (trans.), Vogel, Cao \& Kink (rev. \& ed.). 


\begin{tabular}{|c|c|c|}
\hline :丈, 左右必 & $\begin{array}{l}\text { and night incessantly in } \\
\text { shifts. This [ore] gravel is } \\
\text { pushed out [from the adits] } \\
\text { as [described] before, but } \\
\text { the [way of] hauling it out } \\
\text { of a shaft is somewhat } \\
\text { different, because inside of } \\
\text { it they hang double ladders } \\
\text { made of cowhide more than } \\
\text { ten zhang apart from each } \\
\text { other, while left and right of } \\
\text { them there must be benches } \\
\text { installed for taking a rest } \\
\text { with one's heavy load. The } \\
\text { [ore] gravel is filled into } \\
\text { "pronged bags," one man } \\
\text { carrying } 50 \text { jin on his back, } \\
\text { and bringing it out by } \\
\text { climbing up one after } \\
\text { another. }\end{array}$ & $\begin{array}{l}\text { subinde ita durus est, vt cum quouis filice certare } \\
\text { queat. Alter vero perpetuo mollior \& fragilior } \\
\text { existit. [...] } \\
\text { Qui in fodinis operantur, iugiter ardentib. } \\
\text { candelis vtuntur, sed \& operas ita inter se } \\
\text { partiuntur, vt nonnulli interdum, alij noctu } \\
\text { suffosioni vacent: qua viccissitudine etiam quietem } \\
\text { somnumque captare fueuerunt. Quae eruuntur } \\
\text { metalla, pleraque durissima sunt, adeo, vt } \\
\text { inftrumentis ferreis contusa comminui opus fit. } \\
\text { Fracta \& comminuta, dorsis imponunt, \& in hanc } \\
\text { rem paratis scalis ascendentes, foras efferunt. } \\
\text { Scalae autem tribus ex corio bouino contortis } \\
\text { funibus constant: quibus transuersi baculi, } \\
\text { graduum specie inferuntur aut suffiguntur, ita, vt } \\
\text { duo inuicem occurrentes, commode sibi cedere } \\
\text { queant. Scalarum quaelibet } 10 \text {. orgiarum } \\
\text { longitudinem habet. Eius extremis alia subinde } \\
\text { connectitur. Ad scalarum latera, nonnullibi scamna } \\
\text { ex ligno confecta, ascendentibus quieturis extructa } \\
\text { sunt. Cuiuslibet baculi mensura duorum } \\
\text { Arroborum est. Hoc pondus veste, de pectore } \\
\text { religata, gestant: ternique ex ordine sese semper } \\
\text { insequuntur. }\end{array}$ \\
\hline
\end{tabular}

The chapter closes with the following words:

Since in China ore mountains are so numerous, such an abundance should not only be limited to one place; it is simply that one has not yet obtained here the [right] method to mine them. 38

This last sentence is most remarkable, because it is the only statement within the main text body of the KYGZ in which China is explicitly mentioned, and where reference is made to the purpose of the work, namely, to bring successful Western mining methods to China in order to let her make better use of her - surely existent-mineral riches. Not less remarkable is the preceding part, where the highly productive mine is introduced. Other than De re metallica, KYGZ generally never provides any description of the situation in a particular Western mine as an example for the application of its methods. This makes sense, because the relevant places are far away from the lives of its prospective readers, and knowing about them provides no additional value.

38 “如中土礦山甚多, 如此之富亦不止一處, 但採之不得其法耳。”

KYGZ (3a:25a). Translation: Jost (trans.), Vogel, Cao \& Kink (rev. \& ed.). 
This sole exception is introducing-without giving its name or providing its location-the silver mines of the Cerro Rico in Potosí, then Spanish Peru and now Bolivia. But the provided introduction barely links up with the technical content of the rest of the chapter, and only very limited information about mining methods are provided at all. Those methods that are mentioned, like hauling with "pronged bags" and climbing through "double ladders made of cowhide," seem thoroughly primitive and unimpressive as compared, for instance, to the use of huge and complex waterdriven machines in many European mines of the same time period. Technologies, truly exceptional to silver production in Latin America, like the so-called patio process, ${ }^{39}$ are not brought up.

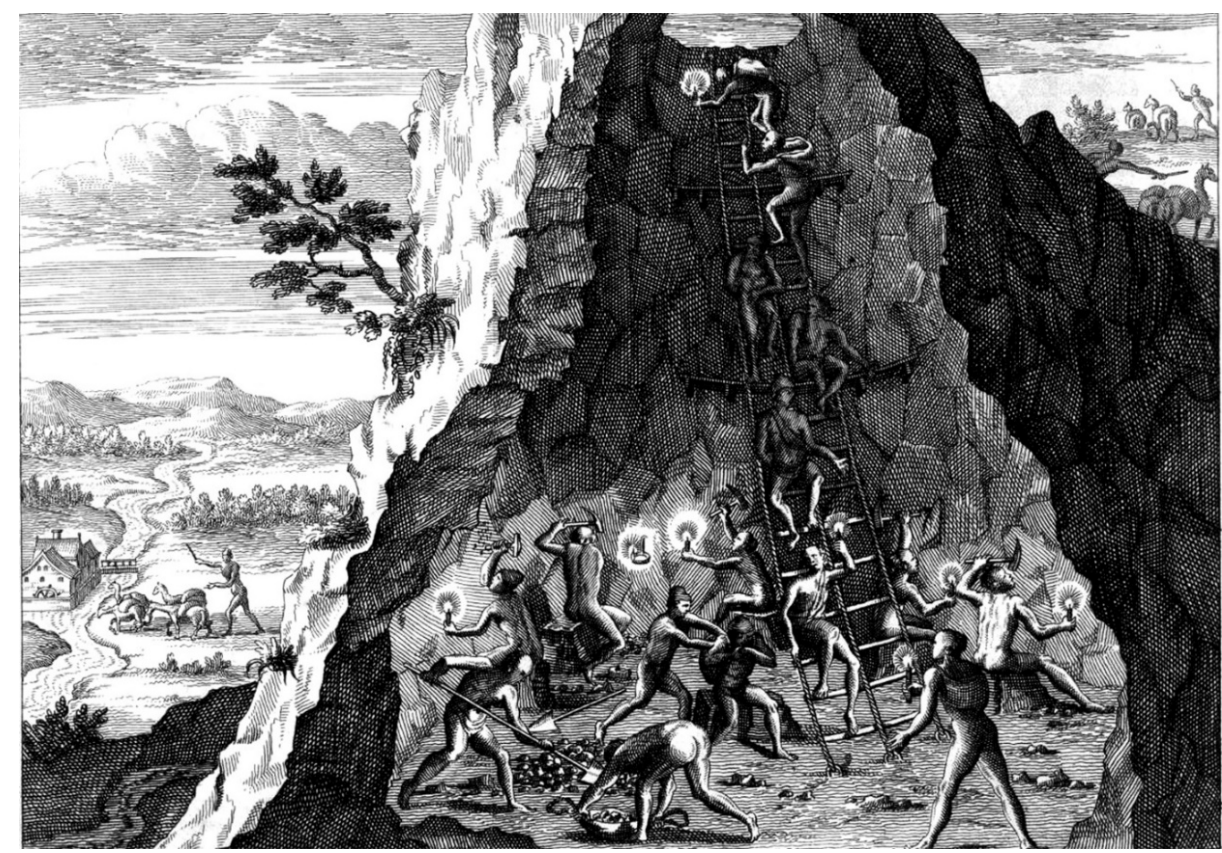

Figure 3: Illustration of the Cerro Rico in Potosí and its silver mine from De Bry's Peregrinationes (De Bry 1602, fifth illustration of the Appendix). Double ladders, resting benches, and hauling bags, items included in the KYGZ text, are all visible in the picture.

Almost all the parts of the text can be identified as direct translations of relevant passages in the Spanish Historia natural y moral de las Indias by José de Acosta (De Acosta 1590). There is nothing to indicate that Schall had access to the Spanish version in Beijing, but a copy of Volume IX of Theodore de Bry's Peregrinationes containing a

39 The patio process is a complex multi-step method to process silver ores by means of amalgamation with mercury, which was developed and applied in Latin American mines (Guerrero 2017). 
Latin translation of the text was brought along by Schreck and Trigault to Beijing, and is still part of the Beitang Collection in the National Library of China today (De Bry 1602; Verhaeren 1949, 322, \#1133). It contains no paratextual remarks in relevant places, though some stains and brush markings elsewhere imply that it was actually read. ${ }^{40}$ Since currently no other version is known to have existed in Beijing at Schall's time, it is safe to assume that this book is the source for the example passage above.

The question remains, however, why Schall chose to include information about Potosí in the KYGZ at all, if it neither directly relates to the chapter it is included in, nor effectively supports his argument that China had sufficient resources, but lacked advanced Western methods. One can merely speculate on this point. One reason may be that Schall was either asked by interested Chinese counterparts to include information on the most flourishing mine in the West into his text, which would surely be Potosí, or, because someone knew about its existence, that he was explicitly asked to write about it, which could resulted from its mention in Giulio Aleni's (1582-1649, Chinese name Ai Rulüe 艾儒略) Record of the Places outside the Jurisdiction of the Office of Geography (Zhifang waiji 職方外紀) (Aleni [Ai] 1623, 8b) seventeen years earlier, where similar information about Potosí is included in a completely different translation (Cao 2018; Schottenhammer 2020). Another possibility is that an illustration in De Bry's book, where the Cerro Rico is depicted in a simplified manner (see Figure 3), aroused someone's interest, and led to the request to include Potosí into the KYGZ.41 In doing so, however, De Acosta's, or respectively De Bry's work, became the only Western source of the KYGZ that is not by itself concerned with mining and metal production, but treats these topics only peripherally.

\section{Concluding remarks}

When searching for the possible origins of knowledge on Western mining and smelting methods needed by Schall for the compilation of his KYGZ, it becomes evident that the three most important works of relevant contemporary literature, along with a number of complementary books, were all available to him. Most of them had reached China together with Johann Schreck and Nicolas Trigault after their acquisition tour through Europe in 1616 and 1617. Schreck himself took a keen interest in mineralogy for

40 The book was inspected by the author during a visit to the National Library of China in 2018. 41 It is possible that Schall consulted this illustration during the writing of his passage about Potosí because all the visible technical practices of mining he includes in the text are shown in it: double ladders, resting benches, and hauling bags. The KYGZ text, however, does not include any mention of this illustration, and has no legend, as is usually the case for other illustrations. Moreover, the volume used by Schall in the National Library in Beijing does not include any glue stains (for tracing paper) or other markings, which generally is the case for illustrations included that were taken from De re metallica. 
medical purposes, but it appears that beyond this, mining, smelting, and assaying were seen as valuable fields of advanced European knowledge as well. Therefore, related literature was deliberately collected and shipped to China, though likely without any pre-conceived concrete intent for systematic knowledge transfer.

While sources describing the compilation process of the KYGZ only mention one Western book (named Kunyu gezhi as well) as a source for translation, a later visitor clearly remarks that Schall proudly kept two sizeable volumes of books about the topic on his shelf. A closer analysis of the rediscovered KYGZ manuscript, however, demonstrates that Schall used at least four other books in at least three different languages besides De re metallica to gather the information he needed.

While there is no question that Georgius Agricola's De re metallica is the most extensively used source, the KYGZ is anything but a translation of this work alone. Following his own structure and attempting to answer questions reaching beyond the scope of De re metallica, Schall spared no efforts to consider all relevant sources at his disposal in order to make the best of his task. This concerned not only, for instance, passages on ore prospection and identification he translated from Biringuccio's Italian text, or on fire control from Fachs's Probierbüchlein, but even at least one large illustration he decided to take over from Lazarus Ercker's work. ${ }^{42}$ The reason why he additionally consulted De Acosta's report about Potosí in De Bry's Peregrinationes remains somewhat unclear, but makes the text, after Aleni's Record of the Places outside the Jurisdiction of the Office of Geography, the second surviving document in Chinese language speaking about the origins of Latin American silver, which by the time of its publication already exerted a remarkable influence on the Chinese economy.

From all these observations it can be concluded that, at least for this process of knowledge transfer concerning a field of most crucial interest to the state, Schall and his collaborators undertook efforts greatly exceeding the task of a mere translation. For this purpose they had large parts of the best literature available at their time to hand, and made thorough use of it. Whether this task was completed in a way that the result could be truly understood by a Chinese reader, and if this understanding could have been transferred efficiently into practice by an official supervising mining and smelting operations is a different question. The good number of sources Schall and his collaborators could work with also does not explain to what extent the successful spread and use of the KYGZ throughout the country could have realistically reformed the Chinese mineral industries, or even could have rescued the Ming treasury. Further

42 Han Fengran $(2015 b, 62)$ speculates that also Agricola's De natura fossilium (Agricola 1546) might have been used for passages in the preface of the $K Y G Z$, replacing two originally intended volumes about the basics of mineralogy. In the course of this research, however, no proof for the availability of De natura fossilium in late Ming China, or for a translation or otherwise inclusion of passages from the latter into the KYGZ, could be identified. 
study is also required to determine whether the KYGZ did in fact still have any kind of impact in China before its disappearance from the public eye. To solve such open questions may require an effort of a size comparable to the one of compiling it.

\section{References}

Adams, Frank D. 1938. The Birth and Development of the Geological Sciences. New York: Dover Publications.

Agricola, Georgius. 1530. Bermannus sive de re metallica dialogus [Bermannus or a Dialogue about Mining]. Basel: Frobenius.

Agricola, Georgius. 1546. De natura fossilium libri X [Ten Books about the Nature of Minerals]. Basel: Hieron. Frobenius.

Agricola, Georgius. 1556. De re metallica libri XII [Twelve Books about Mining]. Basel: Hieron. Frobenius.

Agricola, Georgius, and Philippus Bechius, trans. 1580. Berckwerck Buch [Mining Book]. Frankfurt: Feyerabend. First edition under the title Vom Bergkwerck XII Bücher [Twelve Books about Mining] published by Frobenius in Basel in 1557.

Agricola, Georgius. 1974. Georgius Agricola - Ausgewählte Werke, Vol. VIII (De re metallica libri XII) [Georgius Agricola-Selected Works, Vol. III (De re metallica libri XII)], translated by Hans Prescher and Georg Fraustadt, and edited by Hans Prescher. Zwickau: VEB Deutscher Verlag der Wissenschaften.

Aleni, Giulio, SJ [= Ai Rulüe 艾儒略]. 1623. Zhifang waiji 職方外紀 [Record of the Places outside the Jurisdiction of the Office of Geography], version collected in the National Archives of Japan. Anonymous. 1533. Probierbüchlein [Assaying Book]. Frankfurt: Christian Egenolf.

Bernard, Henri, SJ, ed. 1942. Rélation historique: Lettres et memoirs d'Adam Schall S. J. [Historical Account: Letters and Memoirs of Adam Schall, SJ], translated by Paul Bornet. Tientsin: Hautes Études.

Bernard, Henri, SJ. 1945. "Les adaptations chinoises d'ouvrages europeens. Bibliographie chronologique depuis la venue des Portugais à Canton jusqu'à la mission française de Pékin, 1514-1688" [Chinese Adaptions of European Works. Chronological Bibliography from the Arrival of the Portuguese in Canton until the French Mission to Beijing, 1514-1688]. Monumenta Serica 10:309-388.

Biringuccio, Vannoccio. 1540. De la Pirotechnia libri X [Ten Books about Fire Technology]. Siena: C. Navò.

Cao, Jin 曹晋. 2018. “From Ricci's World Map to Schall's Translation of De Re Metallica: Western Learning and China's Search for Silver in the Late Ming Period (1583-1644)." Crossroads 17/18:93-138.

Cardanus, Hieronymus. 1557. De rerum varietate libri XVII [Seventeen Books on a Variety of Natural Phenomena]. Basel: Heinrich Petri.

Chan, Albert, SJ. 1998. "Johann Adam Schall in the Pei-yu lu of T'an Ch'ien and in the Eyes of His Contemporaries." In Western Learning and Christianity in China: The Contribution and Impact of Johann Adam Schall von Bell, S.J., edited by Roman Malek, 273-302. Nettetal: Steyler.

Colonna, Fabio. 1592. Phytobasanos sive plantarum aliquot historia in qua describuntur diversi generis 
plantae veriores ["Phytobasanos" or a Study of Several Plants, in which Real Plants of Different Types are Described]. Neapoli: Horatio Saluiani.

Darmstädter, Ernst. 1926. Berg-, Probier- und Kunstbüchlein [Small Books on Mining, Probing and (Related) Arts]. München: Verlag Münchner Drucke.

De Acosta, José, SJ. 1590. Historia natural y moral de las Indias [Natural and Moral History of the Indies]. Sevilla: Juan de León.

De Bry, Theodorus. 1602. Americae Nona et postrema Pars [Ninth and Last Part about America]. Frankfurt: Matthias Becker.

Ercker, Lazarus. 1580. Beschreibung der allerfürnemsten Mineralischen Erzt und Bergwerksarten [Description of the Most Prominent Types of Mineral Ores and Mines]. Frankfurt: Feyerabend.

Fachs, Modestinus. 1595. Probierbüchlein. Darinne Gründlicher Bericht vormeldet. wie man alle Metall, und derselben zugehörenden Metallischen Ertzen und Getöchten ein jedes auff seine Eigenschafft und Metall recht Probieren sol. [Probing Book, Therein Careful Report on How to Correctly Assay All Metals and Their Related Ores in Respect to Their Qualities and Metal Content]. Leipzig: Zacharias Berwald.

Freeberg, David. 2003. The Eye of the Lynx: Galileo, His Friends, and the Beginnings of Modern Natural History. Chicago: University of Chicago Press.

Guerrero, Saul. 2017. Silver by Fire, Silver by Mercury: A Chemical History of Silver Refining in New Spain and Mexico, 16th to 19th Centuries. Leiden: Brill.

Guntau, Martin, and Gerhard Mathé. 2013. “Georgius Agricolas Beiträge zur Entwicklung Geologischer Vorstellungen" [Georgius Agricola's Contributions to the Development of Geological Ideas]. In Georgius Agricola, 500 Jahre: Wissenschaftliche Konferenz vom 25.-27. März 1994 in Chemnitz, Freistaat Sachsen [Georgius Agricola, 500 Years: Academic Conference, March 25-27, 1994, in Chemnitz, Saxony], edited by Friedrich Naumann, 90-104. Berlin: SpringerVerlag.

von Goldegg, Hugo, ed. 1875. Vol. 2 of Die Tiroler Wappenbücher im Adelsarchive des k. $k$. Ministerium des Innern zu Wien [The Tyrolean Rolls of Arms in the Nobility Archives of the Vienna Imperial and Royal Ministry of Internal Affairs]. Innsbruck: Wagner.

Golvers, Noël. 2012. Logistics of Book Acquisition and Circulation. Vol. 1 of Libraries of Western Learning: Circulation of Western Books between Europe and China in the Jesuit Mission (ca. 1650-ca. 1750). Leuven: Ferdinand Verbiest Institute KU Leuven.

Golvers, Noël. 2013. Formation of Jesuit Libraries. Vol. 2 of Libraries of Western Learning: Circulation of Western Books between Europe and China in the Jesuit Mission (ca. 1650-ca. 1750). Leuven: Ferdinand Verbiest Institute KU Leuven.

Golvers, Noël. 2015. Of Books and Readers. Vol. 3 of Libraries of Western Learning for China: Circulation of Western Books between Europe and China in the Jesuit Mission (ca. 1650-ca. 1750). Leuven: Ferdinand Verbiest Institute KU Leuven.

Golvers, Noël. 2018. "The Officina Plantiniana in Antwerp as Provider of Books for Jesuits in Early Qing China." In Lux Librorum: Essays on Books and History for Chris Coppens, edited by Goran Proot, David McKitterick, Angela Nuovo, and Paul F. Gehl, 165-199. Mechelen: Flanders Book Historical Society.

Gong, Yingyan 龚纱晏. 2017. “Xu Guangqi wei kan biji Kaicheng jiyao chukao” 徐光启未刊笔记 《开成纪要》初考 [A Preliminary Study of Xu Guangqi's Unpublished Notebook Kaicheng 
jiyao]. Fudan xuebao (shehui kexue ban) 复旦学报（社会科学版） [Fudan Journal (Social Sciences)], no. 4, 53-60.

Gyllenbok, Jan. 2018. Vol. 2 of Encyclopaedia of Historical Metrology, Weights, and Measures. Basel: Birkhäuser.

Han, Fengran 韩风申. 2015a. “Nantu cang Tang Ruowang Kunyu gezhi faxian ji” 南图藏汤若望 《坤與格致》发现记 [A Note on the Discovery of Adam Schall von Bell's Kunyu gezhi stored in the Nanjing Library]. Dongfang zaobao 东方早报 [Oriental Morning Post], April 26, 2015.

Han, Fengran. 2015b. “Nantu cang Yan Jie jiaoben: Tang Ruowang Kunyu gezhi chukao” 南图藏 严杰校本: 汤若望《坤與格致》初考 [A Manuscript Collated by Yan Jie and Stored in the Nanjing Library: A First Investigation into Adam Schall von Bell's Kunyu gezhi]. Zhongguo dianji yu wenhua 中国典籍与文化 [Chinese Classics \& Culture], no. 95, 58-64.

Heyers, Rolf. 1957. Dr. Georg Marius, genannt Mayer von Würzburg (1533-1606) [Dr. Georg Marius, Called Mayer of Würzburg (1533-1606)]. PhD diss., Würzburg University.

Hoover, Herbert C., and Lou H. Hoover. 1950. Georgius Agricola: De Re Metallica - Translated from the First Latin Edition of 1556. New York: Dover Publications.

Jäger, Fritz. 1944. “Das Buch von den Wunderbaren Maschinen. Ein Kapitel aus der Geschichte der Abendländisch-Chinesischen Kulturbeziehungen" [The Book of the Wonderful Machines. A Chapter within the History of Occidental-Chinese Cultural Relations]. Asia Major, Neue Folge, no. 1, 78-96.

Long, Pamela O. 1991. "The Openness of Knowledge: An Ideal and Its Context in 16th-Century Writings on Mining and Metallurgy." Technology and Culture 32 (2, Part 1): 318-355.

Long, Pamela O. 2001. Openness, Secrecy, Authorship: Technical Arts and the Culture of Knowledge from Antiquity to the Rennaissance. Baltimore: John Hopkins University Press.

Malek, Roman. 1998. Western Learning and Christianity in China: The Contribution and Impact of Johann Adam Schall von Bell, S.J. Nettetal: Steyler.

Mao, Ruifang 毛瑞方. 2006. “Guanyu qiqianbu Xishu muji ruogan wenti de kaocha” 关于七千部 西书募集若干问题的考察 [Study on Some Issues concerning the Collection of the Seven Thousand Western Books]. Lishi dang'an 历史档案 [Historical Archives], no. 3, 10-15.

Maximilian I., Elector of Bavaria. 1616. Landrecht, Policey-Gerichts- Malefitz- vnd andere Ordnungen. Der Fürstenthumben Obern vnd Nidern Bayrn. München: Henricus.

Meyer, Georg. 1595. Bergwercks Geschöpff, ond wunderbare Eigenschafft der Metallsfrüchte [The Creature of a Mine and the Wonderful Qualities of Its Metallic Fruits]. Leipzig: Abraham Lamberg \& Henning Gross.

Needham, Joseph, Ho Ping-yu, and Lu Gwei-djen. 1976. Chemistry and Chemical Technology: Historical Survey, from Cinnabar Elixirs to Synthetic Insulin. Vol. 5, part 3 of Science and Civilisation in China. Cambridge: Cambridge University Press.

Needham, Joseph, and Lu Gwei-djen. 1974. Chemistry and Chemical Technology: Spagyrical Discovery and Invention: Magisteries of Gold and Immortality. Vol. 5, part 2 of Science and Civilisation in China. Cambridge: Cambridge University Press.

Needham, Joseph, and Wang Ling. 1965. Physics and Physical Technology: Mechanical Engineering. Vol. 4, part 2 of Science and Civilisation in China. Cambridge: Cambridge University Press.

Pan, Jixing 潘吉星. 1983. “Agelikela de Kuangye quanshu jiqi zai Mingdai Zhongguo de liuchuan” 阿格里科拉的《矿冶全书》及其在明代中国的流传 [Agricola's De re metallica and Its Spread to 
Ming Period China]. Ziran kexueshi yanju 自然科学史研究 [Studies in the History of Natural Sciences] 2 (1): 32-44.

Pan, Jixing, Hans Ulrich Vogel, and Elisabeth Theisen-Vogel. 1989. “Die Übersetzung und Verbreitung von Georgius Agricolas 'De re metallica' im China der späten Ming-Zeit (13681644)" [Translation and Distribution of Georgius Agricola's De re metallica in China during the Late Ming Period (1368-1644)]. Journal of the Economic and Social History of the Orient 32:153-202. Qiu, Guangming 丘光明, Qiu Long 邱隆, and Yang Ping 杨平. 1998. Zhongguo kexue jishu shi: Duliangheng juan 中国科学技术史 - 度量衡卷 [History of Science and Technology in China: Weights and Measures]. Beijing: Science Press.

Resch, Lieselotte, and Ladislaus Buzás, eds. 1975. Theologische, Juristische, Staatswirtschaftliche Fakultät [Faculties of Theology, Law, State Economics]. Vol. 1 of Verzeichnis der Doktoren und Dissertationen der Universität Ingolstadt - Landshut - München 1472-1970 [List of doctors and dissertations at the University of Ingolstadt - Landshut - Munich]. München: Universitätsbibliothek der Ludwig-Maximilians-Universität.

Rühlein, Ulrich. ca. 1500. Ein nützlich Bergbüchlin [A Useful Mining Book], without place, publisher and year (2nd edition 1505 under the title Ein wohlgeordnetes und nützliches Büchlein, wie man Bergwerk suchen und finden soll [A Well-Arranged and Useful Book about How to Search and Find a Mine]. Augsburg, without publisher.

Schall von Bell, Johann Adam, SJ [= Tang Ruowang 湯若望]. 1640. Kunyu gezhi 坤興格致 [Investigation of the Earth's Interior]. Manuscript version Nanjing Library 南京图书馆, call number GJ/EB/120275.

Schall von Bell, Johann Adam, SJ, and Jiao Xu 焦勋. [1643] 2019. Huogong qieyao 火攻彗要 [Essentials of Fire Assaults]. In Ming-Qing zhi ji Xifa junshi jishu wenxian xuanji 明清之際西法軍 事技術文獻選輯 [Selection of Sources on Western Military Technology in the Ming and Qing Periods], edited by Zheng Cheng 鄭誠, 365-570. Changsha: Hunan Science and Technology Press.

Schall von Bell, Johann Adam, SJ. 1665. Historica Narratio de Initio et Progressu Missionis Societatis Jesu apud Chinenses [Historical Account about the Beginning and Progress of the Mission by the Jesuit Society to the Chinese]. Vienna: Cosmerovius.

Schimmelpfennig, Lothar. 2012. "Johann Adam Schall von Bell, Jesuit und Feuerwerker" [Johann Adam Schall von Bell, Jesuit and Fire Craftsman]. Accessed June 10, 2020. http://bdfwt.de/johann-adam-schall-von-bell-jesuit-und-feuerwerker/.

Schottenhammer, Angela. 2020. "East Asia's Other New World, China and the Viceroyalty of Peru: A Neglected Aspect of Early Modern Transpacific History." Medieval History Journal 23 (1): $1-59$.

Schulze, Winfried. 1996. Ego-Dokumente: Annäherung an den Menschen in der Geschichte [Ego Documents: Approaching Humans in History]. Berlin: De Gruyter.

Sisco, Anneliese G., and Cyril S. Smith. 1949. Bergwerk- und Probierbüchlein; a Translation from the German of the Bergbu chlein, a Sixteenth-Century Book on Mining Geology and of the Probierbu chlein, a Sixteenth-Century Work on Assaying. New York: American Institute of Mining and Metallurgical Engineers.

Smith, Cyril S., and Martha T. Gnudi. 1942. The Pirotechnia of Vannoccio Biringuccio. New York: The American Institute of Mining and Metallurgical Engineers. 
Stahleder, Helmut. 2005. Belastungen und Bedrückungen: die Jahre 1506-1705 [Hardships and Burdens: The Years 1506-1705]. München: Dölling und Galitz.

Sun, Yuanhua 孫元化. 1632. Xifa shenji 西法神機 [Miraculous Weapons of the West], woodblock print copy of the twenty-eighth year of the Guangxu reign-period (1902).

Tan, Qian 談遷. 1960. Beiyou lu 北游錄 [Record of Traveling in the North]. Beijing: Zhonghua Book Company.

Väth, Alfons, SJ. 1933. Johann Adam Schall von Bell S.J.: Missionar in China, kaiserlicher Astronom und Ratgeber am Hofe von Peking, 1592-1666 [Johann Adam Schall von Bell, SJ: Missionary in China, Imperial Astronomer, and Advisor at the Court of Beijing, 1592-1666]. Köln: J. P. Bachem.

Verhaeren, Hubert. 1947. "Wang Tcheng et la mécanique" [Wang Zheng and Mechanics]. Le Bulletin catholique de Pékin 34:178-189.

Verhaeren, Hubert. 1949. Catalogue de la Bibliothèque de Pé-t'ang [Catalogue of the Beitang Library]. Pékin: Imprimerie des Lazaristes.

Vogel, Hans Ulrich. 1989. “Georg Agricolas 'De re metallica' in China.” Die Technikgeschichte als Vorbild Moderner Technik 15:41-62.

Vogel, Hans Ulrich. 2015. Sensational rediscovery of a manuscript: The Chinese translation of Georgius Agricolas De re metallica of 1640. Press release. Accessed August 18, 2020. https://www. academia.edu/16465441/Sensational_Rediscovery_of_a_Manuscript_The_Chinese_Translation _of_Georgius_Agricolas_De_re_metallica_of_1640.

Vogel, Hans Ulrich (Fu Hansi 傅汉思), and Cao Jin (trans.). 2016. “Kunyu gezhi jingxian yu shi: Agelikela De re metallica (Kuangye quanshu) 1640 nian Zhong yiben” 《坤與格致》惊现于世阿格里科拉《De re metallica》(《矿冶全书》) 1640 年中译本 [The Sensational Re-appearance of the Kunyu gezhi (Investigations of the Earth's Interior): The 1640 Translation Manuscript of Agricola's De re metallica]. Aomen lishi yanjiu 澳門歷史研究 [Macau Historical Studies], no. 14, 73-87.

Warnecke, Friedrich. 1890. Die deutschen Bücherzeichen (Ex-libris) von ihrem Ursprunge bis zur Gegenwart [German Bookplates (Ex-libris) from Their Beginnings until Present Times]. Berlin: Stargardt.

Williams, Trevor I. 1956. A History of Technology: The Mediterranean Civilizations and the Middle Ages, c. 700 B.C. to c. 1500 A.D. Oxford: Clarendon Press.

Xu, Guangqi 徐光啟. 1857. Kaicheng jiyao 開成紀要 [Record of Essentials of Inception and Completion], year of original compilation unknown, manuscript copy of 1857 by Han Yingbi 韓應陛, Zhejiang Library 浙江图书馆, call number 善 2789/膠 578 .

Xu, Guangqi. 1962a. Zengding Xu Wending gong ji 增訂徐文定公集 [Collected Works of Sir Xu Wending (Xu Guangqi), Revised and Expanded]. Taipei: Chung Hwa Book Company.

Xu, Guangqi. 1962b. Xu Guangqi shouji 徐光啟手跡 [Hand-Written Notes of Xu Guangqi]. Shanghai: Zhonghua Book Company.

Yin, Xiaodong 尹晓冬. 2009. “17 shiqi chuan Hua Xiyang tongpao zhizao jishu yanjiu: Yi Xifa shenji, Huogong qieyao wei zhongxin” 17 世纪传华西洋铜炮制造技术研究一一《西法神机》、 《火攻阷要》为中心 [On the Manufacture of Bronze Cannon Introduced into China in the Seventeenth Century from the West: An Analysis Mainly Based on the Xifa Shenji and Huogong Qieyao]. Zhongguo kejishi zazhi 中国科技史杂志 [The Chinese Journal for the History of Science and Technology] 30 (4): 377-395. 
Zhang, Baichun 张柏春, Tian Miao 田沝, Matthias Schemmel 马深孟, Jürgen Renn 雷恩, and Peter Damerow 戴培德. 2008. Chuanbo yu huitong: “Qiqi tushuo" yanjiu yu jiaozhu 传播与会通一 一《奇器图说》研究与校注 [Transmission and Integration: Qiqi Tushuo (Illustrations and Descriptions of Extraordinary Devices). New Research and Annotated Edition]. Nanjing: Phoenix Science Press.

Zhao, Daying 赵大莹. 2015. “Beitang shu: Ming-Qing Beijing jidujiao tuan cangshu yanjiu” 北堂 书——明清北京基督教团藏书研究 [Beitang Library: Church and Missionary Books in the Ming and Qing Dynasties]. PhD diss., Peking University.

Zheng, Cheng. 2012. “Zhurong zuoli kao: Mingmo Xifa paoxue zhuzuo zhi yuanliu” 《祝融佐 理》考一一明末西法砲学著作之源流 [A Study of Zhurong zuoli: Artillery Handbook in Late Ming]. Ziran kexueshi yanju 31 (4): 457-483.

Zheng, Cheng. 2019. Ming Qing zhiji Xifa junshi jishu wenxian xuanji 明清之際西法軍事技術文獻選 輯 [Selection of Sources on Western Military Technology during the Ming-Qing Transition]. Changsha: Hunan Science and Technology Press.

Zhou, Zhenhe 周振鶴. 2017. Ming-Qing zhiji Xifang Chuanjiaoshi Hanji congkan (di er ji) 明清之際 西方傳教士漢籍叢刊 (第二辑) [Collected Works in Chinese Language by Western Missionaries during the Ming-Qing Transition (Second Series)]. Nanjing: Phoenix Publishing \& Media. 